\title{
Sperm surface changes and physiological consequences induced by sperm handling and storage
}

\author{
Tamara Leahy and Bart M Gadella ${ }^{1}$ \\ Faculty of Science, School of Veterinary Science, University of Queensland, Gatton 4343, Queensland, Australia and \\ ${ }^{1}$ Department of Farm Animal Health and of Biochemistry and Cell Biology, Faculty of Veterinary Medicine, Utrecht \\ University, Yalelaan 2, 3584 CM Utrecht, The Netherlands
}

Correspondence should be addressed to B M Gadella; Email: b.m.gadella@uu.nl

\begin{abstract}
Spermatozoa interact with their immediate environment and this contact remodels the sperm surface in preparation for fertilisation. These fundamental membrane changes will be critically covered in this review with special emphasis on the very specific surface destabilisation event, capacitation. This process involves very subtle and intricate modifications of the sperm membrane including removal of suppression (decapacitation) factors and changes in the lateral organisation of the proteins and lipids of the sperm surface. Processing of sperm for assisted reproduction (storage, sex-sorting, etc.) subjects spermatozoa to numerous stressors, and it is possible that this processing overrides such delicate processes resulting in sperm instability and cell damage. To improve sperm quality, novel mechanisms must be used to stabilise the sperm surface during handling. In this review, different types of membrane stress are considered, as well as novel surface manipulation methods to improve sperm stability. Reproduction (2011) 142 759-778
\end{abstract}

\section{Introduction}

Spermatozoa interact with, and are altered by, their immediate environment and the plasma membrane serves as the two-way communication device. During transit in the male reproductive tract, at ejaculation, and upon entry to the female tract, spermatozoa encounter a host of fluids, epithelial and immunocompetent cells (Amann \& Hammerstedt 1993) from the specialised regions of the epididymis, the accessory sex glands, and the oviduct. The complex and varied protein complement of these fluids prepares the sperm surface for fertilisation. Countless experiments have been undertaken to determine the mechanics of this remodelling process (although they are usually performed under in vitro capacitating/IVF conditions) and the results are the subject of constant review (Flesch \& Gadella 2000, Gadella 2008, Tsai \& Gadella 2009, Ikawa et al. 2010, Reid et al. 2011). The aim of the current review is to overview surface alterations that are important for sperm survival and fertilisation competence and discuss how this knowledge could be implemented to compensate for current shortcomings in sperm processing.

\section{Physiological alterations of the sperm surface}

Modification of the sperm surface in the testis and epididymis

Round germ cells are transformed into fertile spermatozoa by various morphological and surface-modifying events (Gatti et al. 2004). Morphological transformation occurs in the testis where round germ cells undergo division, differentiation and meiosis to form haploid, elongated spermatids in a process known as spermatogenesis. The sperm surface is then further modified in the epididymis by sequential exposure to a highly dynamic protein environment created by regionalised secretion and absorption of proteins across the epididymal epithelium. The varying complement of molecules found in the specialised regions of the epididymal tract has been described in numerous species (pig (Dacheux et al. 1989, Syntin et al. 1996, Guyonnet et al. 2009), bull (Belleannee et al. 2011), stallion (Fouchecourt et al. 2000), rat (Vreeburg et al. 1992, Suryawanshi et al. 2011) and human (Baker et al. 2005, Li et al. 2010, 2011)) including details of all the proteins present (proteome), secreted (secretome) or transcribed (transcriptome), and this information has greatly expanded knowledge of the role of epididymal proteins in sperm maturation (reviewed by Gatti et al. (2004) and Dacheux et al. (2005, 2009)).

These proteins may form weak associations with the sperm surface, such as those reported for certain isoforms of clusterin (Howes et al. 1998), whereas others, such as human epididymal protein (Kirchhoff et al. 1998) or its porcine homologue (Okamura et al. 1999), form strong glycosylphosphatidylinositol (GPI) anchors. Proteins may also be removed or modified by 
proteolytic processing, and some have been reported in the surrounding fluid in active enzymatic form (e.g. angiotensin converting enzyme (Gatti et al. 1999, Metayer et al. 2001)).

Many potential mediators of sperm-egg communication are acquired, or modified, in the epididymis, demonstrating the significant contribution of this organ to successful fertilisation (see Fig. 1). Examples identified through biochemical investigation include GPIanchored proteins (bull: SPAM1 (Morin et al. 2010); mouse: PH20 (Thaler \& Cardullo 1995) and rat: 2B1 glycoprotein (Seaton et al. 2000)), proteins showing carbonyl reductase activity (hamster: P26h (Montfort et al. 2002) and pig (van Gestel et al. 2007)), cysteinerich secretory proteins (mouse and rat: CRISP1 (Roberts et al. 2006, Busso et al. 2007, Da Ros et al. 2008)) as well as the secreted protein containing $\mathrm{N}$-terminal Notch-like type II EGF repeats and C-terminal discoidin/F5/8 C domains type 1 (SED1 in human and rodents (Ensslin \& Shur 2003, Shur et al. 2006, Copland et al. 2009)) and its porcine and bovine homologues, p47 and lactadherin, respectively (Ensslin et al. 1998, van Gestel et al. 2007), and in the pig the spermadhesin AQN3, which is secreted in part from the cauda epididymis and mainly from the seminal vesicles (van Gestel et al. 2007). Integral membrane proteins of testicular origin such as proteins of a disintegrin and metalloprotease (ADAM) family have also been described to function in spermoocyte interaction and fertilisation (Evans 2001). Further insight into these putative sperm-egg receptors has been gained by the use of knockout mice models. Some wellknown gene products (e.g. the ADAM protein fertilin $\beta$ ) were shown to be largely dispensable for in vivo fertilisation (for review, see lkawa et al. (2010)) or have

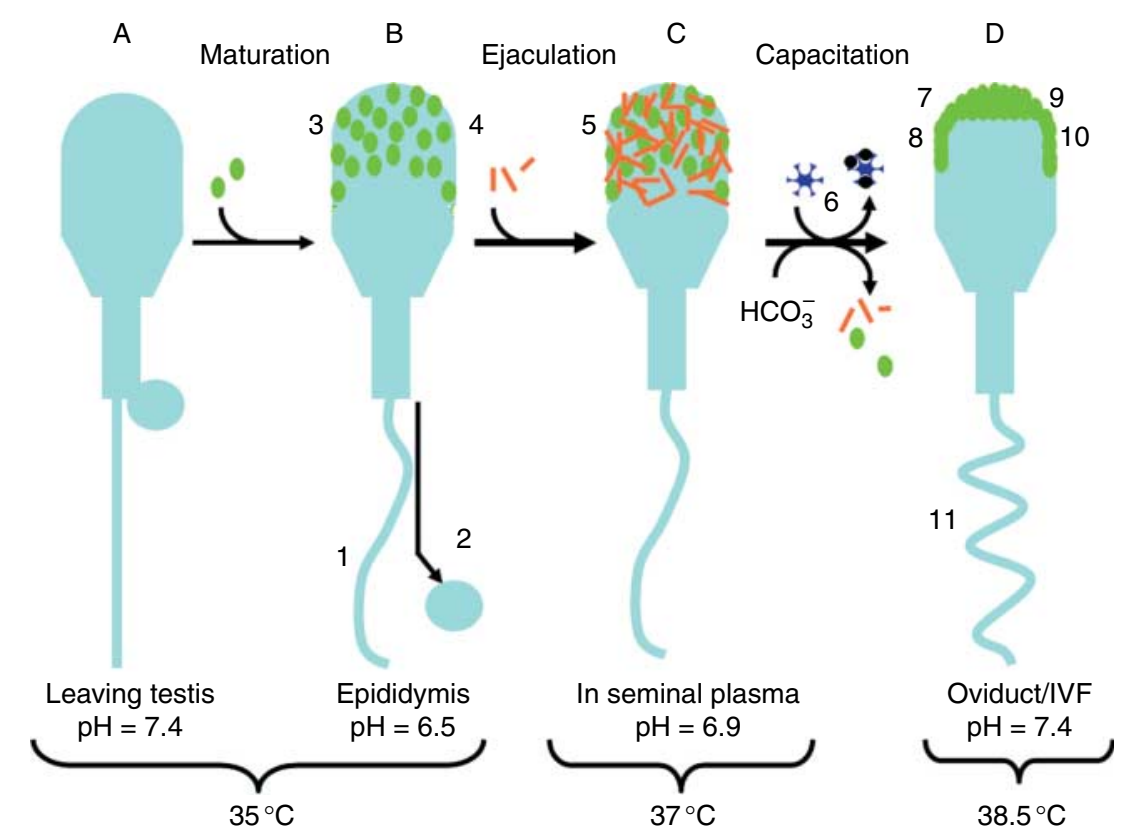

Figure 1 Physiological sequence of surface changes rendering spermatozoa fit to fertilise the oocyte. (A) When spermatozoa leave the testis, they are morphologically complete but lack the capacity to fertilise the oocyte as they are immotile and contain remnants of the cytosolic bridges that synchronise spermatogenic cells until spermiation (the cytoplasmic droplet). (B) In the epididymis, spermatozoa (1) acquire motility characteristics, (2) lose the cytoplasmic droplet and (3) undergo some final chromatin condensation. The sperm surface undergoes various molecular alterations. The most important being the adsorption of proteins (green) that are involved in sperm-zona binding (4) and surface stabilising factors. (C) At ejaculation, spermatozoa are mixed with seminal plasma from the accessory sex glands. Seminal plasma glycoproteins (orange) adhere tightly to the sperm surface and efficiently stabilise the cell during transport through the lower portion of the female genital tract (5). (D) When spermatozoa reach the upper portion of the female genital tract (the isthmus of the oviduct), they are triggered to capacitate. The mechanisms are unknown but it is thought that migration of spermatozoa through the uterus and the uterotubal junction causes the removal of decapacitation factors (orange) and that spermatozoa respond to female-derived stimulatory signals (Holt \& Fazeli 2010). In vitro, this response is elicited after density gradient washing (which strips decapacitation factors originating from the epididymis and accessory sex glands from the sperm surface) and incubation with capacitation factors such as bicarbonate and albumin. This treatment elicits a number of parallel surface changes: (6) cholesterol (black) is oxidised and removed from the sperm surface by albumin (blue), (7) epididymal proteins (green) aggregate into membrane rafts at the apical ridge of the sperm head, (8) a partial lipid scrambling takes place in the same area (9) and seminolipids migrate towards the equatorial area of the sperm head. At the cytosolic site, the apical ridge of the sperm head is now efficiently and stably docked to the outer acrosomal membrane (10). Functionally, the apical head area is now prepared for fertilisation as it contains protein complexes capable of interacting with the zona pellucida or the extracellular matrix of the cumulus mass. It is also likely that ROS formation is an essential part of this signalling system and that it may continue even after capacitation and, in the long-term, induces sperm deterioration (similar to Fig. 2C). At the sperm tail, an increase in the pH of the fluid environment evokes proton extrusion and signal transduction cascades provoke tyrosine phosphorylation events, which generate hyperactivated motility, probably by enhancement of anaerobic ATP generation (11). For further details and references, see section 'Physiological alterations of the sperm surface'. 
alternate mechanisms, such as ADAM3, which was shown to promote sperm migration through the uterotubal junction (Yamaguchi et al. 2009). Furthermore, new candidate genes essential for sperm-egg fusion were discovered (e.g. IZUMO1 (Inoue et al. 2005)).

The sterols and fatty acids of the sperm membrane also undergo significant remodelling during epididymal transit, causing dramatic alterations in membrane architecture. The extent of these changes is highly species specific (reviewed by Saez et al. (2011)). In ram, rat and mouse spermatozoa, cholesterol content decreases $(\sim 50 \%)$ during epididymal transit and the ratio of unsaturated fatty acids increases. However, few changes have been observed in the boar. These lipid modifications increase membrane fluidity and are thought to prime signalling pathways that regulate capacitation because testicular and caput spermatozoa are not responsive to stimuli that capacitate caudal spermatozoa (Yanagimachi 1994, Shadan et al. 2004).

From the information above, it is evident that the proteins and lipids of the plasma membrane are remodelled in the epididymis to prime spermatozoa to undergo capacitation, interact with the zona pellucida and fuse the oolemma (see Fig. 1). In general, it is proposed that spermatozoa from the cauda epididymis are now fit to fertilise.

\section{Seminal plasma and the sperm surface}

Upon ejaculation, spermatozoa are mixed with another set of surface remodelling components derived from the accessory sex glands and are deposited in the female tract. In the oviduct, spermatozoa undergo a final biochemical and structural modification, collectively termed capacitation, which culminates in the acrosome reaction and fertilisation. To attempt to synchronise capacitation with the arrival of spermatozoa at the oocyte, molecules present on the surface of the spermatozoa, and in its immediate environment, act in concert to both stimulate and inhibit the onset and progression of this process (Bedford 2004). An early capacitation-related event is the loss, modification and redistribution of molecules on the sperm surface (Gadella et al. 1995). Entities that coat the sperm membrane and are removed during capacitation are termed decapacitation factors (Bedford \& Chang 1962, Yanagimachi 1994) as their presence is thought to stabilise the sperm membrane and keep it in a noncapacitated state (see Fig. 1). These factors are present in the epididymal fluid and seminal plasma and their mechanisms of action are highly complex and species dependent.

Nixon et al. (2006) showed that CRISP-1 was released from the mouse sperm membrane following capacitation and that its subsequent re-addition inhibited in a dosedependent fashion, a range of capacitation indicators including tyrosine phosphorylation of the sperm plasma membrane and the ability of spermatozoa to undergo the acrosome reaction and bind to the zona pellucida. The mechanism of action of CRISP-1 is unknown but it shares structural similarity with toxin molecules capable of blocking ion channels, and it is thought that it may inhibit the uptake of ions, such as $\mathrm{Ca}^{2+}$, required for capacitation (Koppers et al. 2011). Other decapacitation factors identified by Nixon et al. (2006) include plasma membrane fatty acid binding protein, decapacitation factor 10, and phosphatidylethanolamine binding protein 1 . Although, the latter is likely to be a receptor (Gibbons et al. 2005) for a well-known $40 \mathrm{kDa}$ glycoprotein characterised as a decapacitation factor by Fraser (1984) over two decades ago. Binding of this $40 \mathrm{kDa}$ decapacitation factor to spermatozoa stimulates a calmodulin-sensitive $\mathrm{Ca}^{2+}$-ATPase, which helps to maintain low intracellular $\mathrm{Ca}^{2+}$ levels (AdeoyaOsiguwa \& Fraser 1996). A mouse seminal vesicle auto-antigen has also been described as a potential candidate to maintain low intracellular levels through targeted regulation of membrane sphingolipids and plasma membrane $\mathrm{Ca}^{2+}$-ATPase (Lu et al. 2010).

Decapacitation factors of seminal plasma origin are best described in production animals (e.g. ram, bull and boar) where they have been shown to prevent or reverse capacitation of spermatozoa under conditions of handling-induced stress (Topfer-Petersen et al. 1998, Manjunath et al. 2007, Maxwell et al. 2007, Kirkwood et al. 2008, Muino-Blanco et al. 2008). Further discussion of these agents is provided in section 'Novel sperm surface manipulation methods'.

\section{In vitro capacitation induces sperm surface alterations that enable the spermatozoon to fertilise the egg}

The capacitation process has been observed in vitro through studies that attempt to mimic conditions in the oviduct. In vivo, spermatozoa undergo extreme selection because only a small number of competent spermatozoa are able to cross the uterotubal junction and interact with the epithelium of the oviduct (Sostaric et al. 2008, Suarez 2008, Holt \& Fazeli 2010, Ikawa et al. 2010). It is not well understood how these cells achieve capacitated properties but it is believed that initiation of the process precedes release from oviductal epithelial cells (Lefebvre \& Suarez 1996, Fazeli et al. 1999) and may be triggered by specific oviductal fluid factors that are released on the initiation of ovulation (Overstreet et al. 1978, Hunter 2008, Sostaric et al. 2008). This final maturation enables the spermatozoon to recognise and penetrate the cumulus mass and zona pellucida, fertilise the oocyte by fusing with the oolemma and initiate embryonic development (Rodriguez-Martinez 2007, Brussow et al. 2008).

These conditions are mimicked in vitro by washing ejaculated spermatozoa through a preparative density gradient, which causes a partial stripping of more loosely 
associated extracellular coating material (Martins et al. 2003, Caballero et al. 2009) and may also remove decapacitation and stabilising factors (Fraser 1984). In some species, additional factors are included, such as negatively charged polysaccharides (e.g. heparin with bull spermatozoa (Parrish et al. 1988)), to further enhance stripping of extracellular sperm coating material, possibly mimicking the surface effects elicited by glycosaminoglycans that are present in oviductal fluids (Parrish et al. 1989, Coy et al. 2008, Killian 2011).

Washing allows selection of a sperm population with the highest density, representing cells with signs of superior maturation (higher condensation of chromatin and removal of cytoplasmic droplets). Typically, such cells show considerably lower rates of intrinsic morphological and functional abnormality and reduced signs of peroxidative and/or apoptotic-like response; which in part relates to the removal of immature spermatozoa but also to reduced contamination of leukocytes that actively produce reactive oxygen species (ROS; Sakkas et al. 2000, Aitken et al. 2007, Fariello et al. 2009). Further selection can be achieved using a swim-up procedure to select the most motile sub-fraction of sperm cells, and these procedures are common practice for IVF (for review, see Mortimer (2000)).

The spermatozoa can now respond to a capacitationsupportive medium, which resembles that of oviductal fluid but is more extreme than normal physiological surroundings. For example, the spermatozoa are exposed to a higher temperature $\left(39^{\circ} \mathrm{C}\right.$ instead of $35^{\circ} \mathrm{C}$ ) and artificially raised levels of known capacitating agents (for review, see Gadella \& Visconti (2006)).

Incubation with bicarbonate and calcium ions triggers adenylate cyclase/cAMP/protein kinase $\mathrm{A}$ and tyrosine kinase signalling pathways (Visconti et al. 1995), which induces a partial scrambling of aminophospholipids (Elliott \& Higgins 1983, Gadella \& Harrison 2000). Fatty acid-free BSA is also often included in capacitationsupportive medium because it extracts sterols (Flesch et al. 2001) from the sperm surface, further enhancing membrane fluidity. These changes cause small lipidordered domains, which initially reside over the entire acrosomal region of the sperm plasma membrane, to aggregate in lipid rafts at the apical plasma membrane (see Fig. 1). These lipid rafts are enriched in cholesterol, glycosphingolipids (Lin \& Kan 1996, Visconti et al. 1999, Flesch et al. 2001, Selvaraj et al. 2009) and seminolipids (Gadella et al. 1994, 1995), and this lipid aggregation creates lateral heterogeneity of sperm membrane proteins (Lucero \& Robbins 2004). Certain proteins, such as flotillin and caveolin (Anderson 1998, van Gestel et al. 2005a), are well known to be permanently associated with lipid rafts, but since these structures aggregate in the exact area of the sperm head where initial zona recognition occurs (Cross 2004), they would be expected to also contain zona binding proteins. Indeed, lipid rafts isolated from in vitro-capacitated mouse (Nixon et al. 2009), human (Nixon et al. 2011) and porcine (van Gestel et al. 2005a, 2007) spermatozoa were highly enriched in zona binding proteins. Therefore, it is likely that in vitro capacitation leads to delicate sperm surface alterations, which allow the formation of a multi-protein complex involved in zona recognition (for review, see Gadella (2010)).

Furthermore, it was recently demonstrated that during in vitro capacitation, porcine sperm cells show a characteristic redistribution of SNARE proteins into the same area where the aggregation of membrane rafts and zona binding proteins occurs (Tsai et al. 2007, 2010). SNARE proteins are involved in the execution of the acrosome reaction (Mayorga et al. 2007, Tomes 2007), but rather than inducing membrane fusion, this redistribution caused a very stable docking of the apical plasma membrane with the outer acrosomal membrane. This interaction involved the formation of trans trimeric SNARE complexes of SNAP23, VAMP3 and syntaxins (Tsai et al. 2010), which were stabilised by complexins (Zhao et al. 2007) and probably other factors (PS Tsai, IA Brewis \& BM Gadella, unpublished results).

Subsequent binding with the zona pellucida, or cumulus oophorus complex surrounding it Jin et al. 2011, Yanagimachi 2011), invokes a rise in intracellular $\mathrm{Ca}^{2+}$ (Arnoult et al. 1996, Breitbart 2002), which triggers a calcium-sensitive conformational change from a trans- to cis-SNARE complex (for model, see Tsai et al. (2010)) resulting in multiple-point fusions, or the acrosome reaction. Thus, this prior docking is thought to localise multiple-point fusions at the apical sperm head, where primary binding takes place, leaving the equatorial region of the sperm head intact for subsequent fertilisation fusion with the oocyte (for review, see Gadella \& Evans (2011)).

Taken together, this research suggests that spermatozoa undergo complex ergonomic changes during capacitation. Processing of spermatozoa for assisted reproduction subjects the cells to numerous stressors and it is not known how these disturb the delicate processes outlined above. Stressors associated with storage and sex-sorting, and their consequent alterations of the sperm surface, are discussed in the next section and are visually outlined in Fig. 2.

\section{Sperm surface alterations during sperm handling \\ Cryopreservation}

Long-term storage permits the banking of gametes from high-merit animals, the possibility to check the health status of samples and to internationally distribute superior genetics (Vishwanath 2003, Bailey et al. 2008). Cryopreservation is possible because of the fortuitous discovery of the cryoprotective properties of glycerol (Polge et al. 1949), and requirements for cooling, freezing and thawing of spermatozoa were 


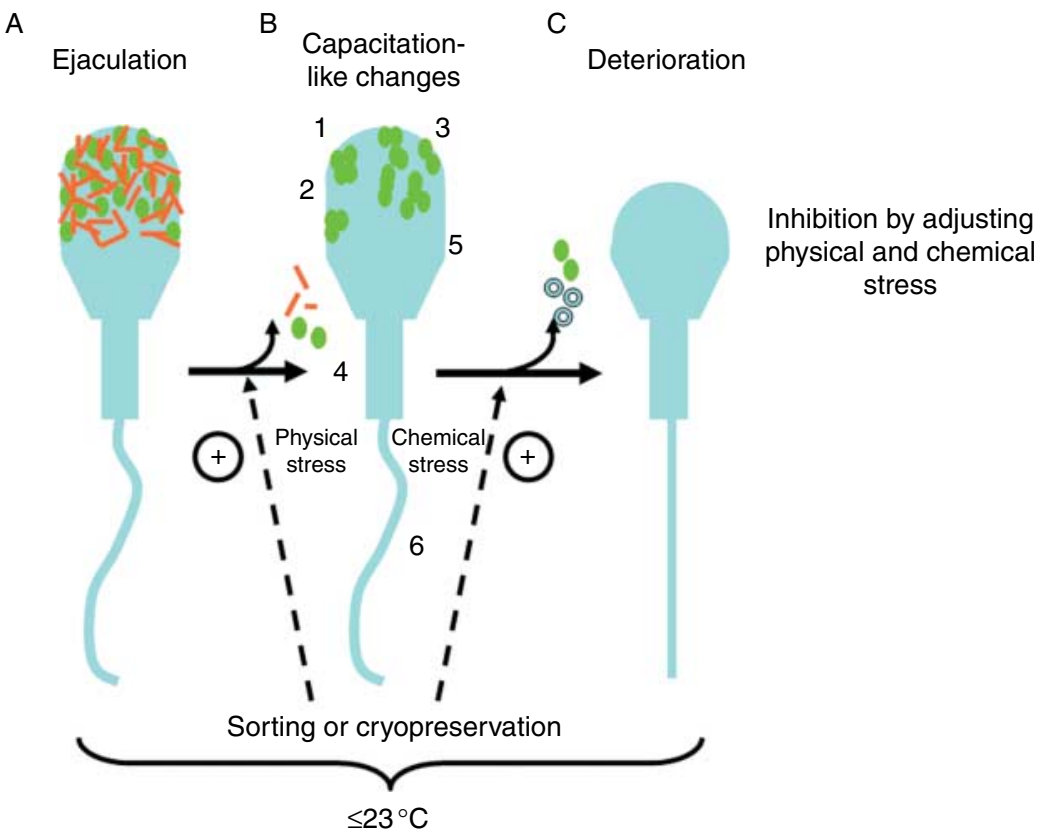

Figure 2 Effects of sperm handling on the sperm surface. (A) Spermatozoa destined for in vitro processing are usually obtained by artificial vagina or electroejaculation (at this point, they have similar surface properties to Fig. 1C). Subsequent processing for technologies such as sex-sorting and cryopreservation affect the sperm surface. (B) Dilution, washing steps and shear forces (flow cytometry) strip decapacitation factors (orange) from the sperm surface. This normally occurs during physiological capacitation (see Fig. 1D) but physical stripping of proteins from the sperm surface does not result in a capacitation-associated aggregation of micro-domains to the apical ridge area. Instead, local micro-aggregation of proteins (1) is shown by capacitation markers (e.g. Merocyanine 540). In addition, changes in temperature, buffers, osmolytes and pressure (sorting) may cause changes in sperm surface properties. This can include either one or more of the following: phase separation of lipids in the sperm plasma membrane (2), acrosome loss (3), lethal ROS production and apoptotic-like changes such as extended phospholipid scrambling and depolarisation of the inner mitochondrial membrane (4) and concomitant lipid peroxidation and DNA damage (5). Moreover, at the tail, these changes also result in ROSinduced tyrosine phosphorylation (which usually activates hyperactivated motility) despite the fact that the spermatozoa are immotile (6). (C) The end result is plasma membrane damage, the release of protein and vesicles (in blue) from the sperm membrane and cell deterioration. These physical and chemical stressors can be minimised by specific protocol adaptations mentioned in the text (see section 'Sperm surface alterations during sperm handling' and Fig. 3). In general, spermatozoa that survive handling appear to have similar surface properties to ejaculated spermatozoa. For further details and references, see section 'Sperm surface alterations during sperm handling'.

formulated in the early 1970s. Optimisation of the process and tailoring for individual species were achieved through countless, continuing, empirical investigations (for species' specific information, see bull (Vishwanath \& Shannon 2000), ram (Salamon \& Maxwell 2000), boar (Johnson et al. 2000, Grossfeld et al. 2008, Rath et al. 2009a) and mouse (Nakagata 2000)). The principles of cryobiology and the considerations made in the past and present to improve the process are valid for many species. Thus, cryopreservation protocols are fairly similar with slight tailoring of conditions to address the eccentricities of some species (e.g. high glycerol content required for koala spermatozoa (Zee et al. 2008)). Synthetic freezing diluents commonly contain tris or citrate to provide an isotonic environment and buffer $\mathrm{pH}$, glucose or fructose as an energy source and non-penetrating and penetrating factors to protect spermatozoa from freeze-thaw damage, such as egg yolk and glycerol.

It is accepted that egg yolk minimises cold shock damage, but its mechanism of action is debated. Direct associations between the lipids of the egg yolk and the sperm membrane have been reported (Pace \& Graham 1974, Ollero et al. 1998, Ricker et al. 2006), and it is believed that these have a stabilising effect, minimising lateral phase separations involved in cold shock deterioration (Pettitt \& Buhr 1998).

Glycerol and other penetrating cryoprotectants (e.g. dimethyl sulphoxide and polyvinyl pyrrolidone) are used to protect the cell interior and prevent intracellular ice formation. However, inclusion of such agents must be carefully managed to minimise potentially detrimental osmotic effects. Spermatozoa can then be frozen, and a rate of $-30^{\circ} \mathrm{C} / \mathrm{min}$ has been shown optimal for boar spermatozoa through determination of the rates of water permeability by differential scanning calorimetry (Devireddy et al. 2004) and rapid thawing is recommended (1200-1800 ${ }^{\circ} \mathrm{C} / \mathrm{min}$ (Hernandez et al. 2007 b)).

In spite of considerable research, the cryopreservation process remains highly damaging, inflicting significant lethal and sub-lethal effects on spermatozoa (Parks \& Graham 1992, Salamon \& Maxwell 1995b, Bailey et al. 2000, Holt 2000, Bagchi et al. 2008). It is routinely and successfully applied only in certain species (e.g. the bull) 
and the reasons for this are numerous and based on both biochemical and practical differences. For example, to overcome inefficiencies of sperm transport from freezethaw damage, spermatozoa must be deposited closer to the site of fertilisation, and this is easier to achieve in the cow, for instance, than in the ewe. In addition, some species show greater susceptibility to freeze-thaw damage (e.g. the pig).

Another confounding factor is the variation between animals in the ability of their spermatozoa to withstand freeze-thaw damage. In the boar, this is the major factor (70\%) affecting cryosurvival (Roca et al. 2006), but this phenomenon is common in many species (bull (Chaveiro et al. 2006), mouse (Songsasen \& Leibo 1997) and dog (Yu et al. 2002)) and influences whether donors can be used for cryopreservation. The reason for this significant male variation is not well understood but numerous causes, and potential markers, of freezing resistance have been investigated including regulation of cell volume (Chaveiro et al. 2006), genetic factors (Thurston et al. 2002), expression of housekeeping proteins (Casas et al. 2009, 2010) and seminal plasma proteins (Jobim et al. 2004, Asadpour et al. 2007).

Differences in freezing resistance also exist between, and within, ejaculates. In fact, in a given boar semen sample, a subpopulation of sperm cells has been identified that exhibit increased osmotic resistance and these cells would be expected to have inherently different membrane changes upon cryopreservation than the spermatozoa in other subpopulations (Petrunkina \& Töpfer-Petersen 2000, Druart et al. 2009).

In the current review, we will only discuss alterations to the primary site of injury, the sperm membrane, and focus particular attention on how this damage may affect its protein and lipid components.

Freezing results in the concomitant coating and decoating of proteins of the sperm surface. Bull (Ollero et al. 1998) and boar (Huang et al. 2009) sperm surface proteins, collected before and after freeze-thawing, showed processing related differences using comparative SDS-PAGE analysis, but the effect of these protein alterations on sperm function remains unknown. The intensity of a fertility-associated protein (P25b; Parent et al. 1999) has also been shown to remain stable if bull spermatozoa were stored in liquid nitrogen for $<5$ days but longer storage periods ( $>28$ days) reduce its abundance compared with that of fresh spermatozoa (Lessard et al. 2000). This result is interesting because it suggests that cryo-elution of the protein occurred in an environment where chemically and thermally driven reactions are minimised, and not during cooling or thawing where the majority of damage to the plasma membrane occurs.

Freeze-thawing also has distinct effects on the lipids of the sperm membrane (Buhr et al. 1994). Temperature fluctuations and cell dehydration induce changes in lateral-phase separation of lipids and thus a lateral reordering of membrane components (Holt \& North 1984, De Leeuw et al. 1990, Drobnis et al. 1993) and the loss of polyunsaturated fatty acids and cholesterol (Maldjian et al. 2005, Chakrabarty et al. 2007). This alters the permeability of the sperm surface to water, ions and cryoprotectants (Hagiwara et al. 2009, Oldenhof et al. 2010) and the final result is a weakening of the cell that reduces its ability to withstand future stress (see Fig. 2). However, at the same time, proteins and lipids of the cryoprotective diluent (e.g. milk, albumin or yolk) coat the membrane, providing partial protection from these deleterious effects of freezing (Ollero et al. 1998, Ricker et al. 2006), and prevent the binding of proteins that are detrimental for sperm survival (Bergeron et al. 2004).

The main advantage of cryopreservation is that it permits an indefinite hiatus of sperm development. However, spermatozoa are altered by this process and when revived by warming, they emerge in an advanced state characterised as a bypassing of the need for capacitation (Watson 1995, Maxwell \& Watson 1996, Maxwell \& Johnson 1997), for they possess the ability to undergo the acrosome reaction. This phenomenon is believed to follow a different pathway to that of physiological capacitation. Green \& Watson (2001) found that lipid bilayer fluidity and tyrosine phosphorylation signalling pathways differed between boar spermatozoa that were cooled $\left(5^{\circ} \mathrm{C}\right)$ and re-warmed from those that were capacitated in vitro. Variations in protein tyrosine phosphorylation patterns between in vitro capacitated and cryopreserved spermatozoa have also been demonstrated in a number of species (bull (Cormier \& Bailey 2003), boar (Bravo et al. 2005) and stallion (Thomas et al. 2006)).

It is speculated that a loss of cholesterol during freezing, and an increase in permeability of the sperm membrane to stimulating factors, allows frozen-thawed spermatozoa to bypass the physiological capacitation pathway. However, it is noteworthy that it has not been demonstrated that these signalling differences result in altered physiological capacitation outcomes (e.g. aggregation of rafts at the apical plasma membrane or docking of the apical plasma membrane with the outer acrosomal membrane; see section 'Physiological alterations of the sperm surface'). Impairment of these processes probably relates to the poor fertility of frozen-thawed spermatozoa following artificial insemination. In fact, lateral phase separation of lipids in frozen spermatozoa is not reversibly restored upon thawing (De Leeuw et al. 1990), which may well impede the capacitation-specific lateral rearrangements of the sperm surface.

The cryopreservation process as a whole dramatically alters the composition of the sperm membrane and its extracellular matrix. In this respect, some surface changes are reversible while others are fatal (Watson 2000, Guthrie \& Welch 2005). A similar effect is evident after spermatozoa are processed for sex-sorting. 


\section{Sex-sorting}

New technologies have allowed the precise selection of subpopulations of spermatozoa with specific attributes. Selection of high-quality spermatozoa via flow cytometry (Paasch et al. 2007) magnetic sorting (Said et al. 2008) or microfluidic sorting (Wu et al. 2006) has proven useful for human ART (Lee et al. 2010) and it is even possible to sort viable sperm cells that are responsive to capacitation from those that are not (de Vries et al. 2003). Despite these possibilities, sorting is only routinely applied to separate $X$ and $Y$ chromosomebearing spermatozoa for the production of offspring with pre-selected sex. This technique exploits differences in DNA content (Johnson et al. 1989) between the $X$ and $Y$ chromosomes, which can be detected by fluorescenceactivated cell sorting after staining with a DNA binding dye (Hoechst 33342, a bisbenzimide-based membrane permeable probe). The technique has now been successfully applied to a wide range of species, produced innumerable live offspring after artificial insemination, and has been the subject of many reviews (Maxwell et al. 2004, Garner 2006, Bathgate 2008, Rath et al. 2009b, Vazquez et al. 2009). Despite its considerable advantages, industry adoption has been hampered by the additional expense and reduced capabilities of sex-sorted spermatozoa compared with their non-sorted counterparts (Rath et al. 2009b).

Sex-sorting exposes spermatozoa to multiple stressors, and while the individual contribution of each is hard to quantify, their combined effect causes advanced cell deterioration. Damage to spermatozoa during sexsorting has been well documented and extensively reviewed (see Garner (2001), Bathgate (2008), Rath et al. (2009b) and Vazquez et al. (2009). Thus, in this review, we will only describe these briefly and focus particular attention on how the sperm surface is affected.

The most limiting aspect of sex-sorting is the length of processing. The low sort rate $\left(\sim 20 \times 10^{6}\right.$ spermatozoa of each sex per hour (Garner 2006)) requires the holding of spermatozoa in sub-optimal conditions for an extended period of time and is the main contributor to their increased cost. Technical improvements have increased sorting speed, but since each cell must be analysed individually, there are limitations on further improvement in this area. Thus, considerable man-hours have been invested into improving sorting conditions.

One of the most obvious differences between nonsorted and sorted sperm populations is their rate of dilution. During sorting, the sperm cells are highly diluted (5000- or 800 -fold in the ram and boar respectively) and the media utilised are species specific and differ with the stage of processing (pre-sorting, sorting and post-sorting). These processing requirements expose spermatozoa to varying buffers, energy sources, protective coating factors (egg yolk and seminal plasma) and consequential fluctuations in osmolarity and $\mathrm{pH}$
(Bathgate 2008). Variations in temperature also occur when spermatozoa are transferred from incubation with Hoechst $\left(34{ }^{\circ} \mathrm{C}\right)$ to the thin tubing of a room temperature-conditioned flow cytometer $\left(24^{\circ} \mathrm{C}\right)$ and this sudden decrease in temperature can cause deterioration of capacitated cells (Flesch et al. 2001). The spermatozoa also face hydrodynamic pressure changes, orientating forces and are subjected to changes in electric charge. The consequences of these insults are largely unknown. Moreover, spermatozoa are exposed to significant mechanical insult when they are propelled through the machine and into a collection vessel at speed up to $90 \mathrm{~km} / \mathrm{h}$ (Seidel \& Garner 2002). Due to their highly dilute state, they are then re-concentrated to obtain an adequate insemination dose. This is commonly achieved through centrifugation, which may further stress the sperm membrane (Leahy et al. 2010a) and generate ROS (Agarwal et al. 1994, Shekarriz et al. 1995) and/or DNA damage (Twigg et al. 1998, Urrego et al. 2008). In the boar, concentration by sedimentation is a promising alternative and has been shown to increase the proportion of viable, motile and fertile spermatozoa after a $16-18 \mathrm{~h}$ storage $\left(17^{\circ} \mathrm{C}\right)$ period (Garcia et al. 2007).

These mechanical and chemical stressors alter the sperm surface (see Fig. 2). Spinaci et al. (2006) reported heat shock protein 70 (HSP70) redistributed from the equatorial sub-segment towards the equator of sperm cells after sorting; a relocation that reflects capacitationlike changes of the sperm membrane. Similarly, capacitation-like changes have been reported in numerous species after flow sorting (ram (Hollinshead et al. 2003), bull (Moce et al. 2006) and boar (Maxwell \& Johnson 1997)). This is not particularly surprising as the processing steps for sorting are very similar to those previously described for in vitro modelling of capacitation. For example, spermatozoa are diluted and subjected to mechanical forces (sheath fluid pressure, expulsion from machine, centrifugation, etc.), which may promote the release of proteins from the sperm surface that are not discharged under physiological conditions (Nixon et al. 2006) and incubated with BSA, a known capacitating agent, during staining and post-sort collection. A combination of these factors is believed to result in the removal or alteration of binding sites on the sperm surface (Maxwell et al. 2007). Indeed, early proteomic studies on the surface of bull spermatozoa reported that sex-sorting caused the loss of two membrane proteins, 108 and $57 \mathrm{kDa}$, thought to originate from seminal plasma and the sperm membrane respectively (McNutt \& Johnson 1996). Conversely, proteins of low molecular weight $(<29 \mathrm{kDa})$, thought to be mainly of seminal plasma origin, were reported to remain adsorbed (McNutt \& Johnson 1996). More recently, binder of sperm proteins (BSP) were reported on the membrane of non-viable ram spermatozoa gated out in the waste population during sorting, confirming 
that seminal plasma proteins remain tightly associated with the sperm membrane during transit through the flow cytometer (Leahy et al. 2011).

Despite the aforementioned stressors, not all the effects of sex-sorting are negative. The orientating forces of the nozzle selects morphologically normal spermatozoa and counterstaining with non-toxic red food dye (FD\&C40) penetrates the nuclear membrane of nonviable cells, quenching Hoechst 33342 fluorescence, and allowing these cells to be gated out to waste during flow sorting. This leaves a population of spermatozoa that exhibit some improved sperm parameters (e.g. membrane integrity and total motility) compared with their non-sorted counterparts (ram (de Graaf et al. 2006) and bull (Underwood et al. 2009c)). This was also noted in a proteomic investigation (Leahy et al. 2011), which showed a greater abundance of sperm membraneassociated protein 1 (SLLP1) in the waste sperm population compared with the final sex-sorted product. This protein is retained on the sperm membrane following acrosomal exocytosis, providing strong evidence that acrosome-reacted spermatozoa are gated out of the final sorted population.

These results show that sex-sorting is a discriminatory process that produces a sperm population that exhibits both superior and inferior traits compared with nonsorted spermatozoa, but which essentially have a limited lifespan. These changes are reflected in reduced fertility rates and higher incidence of pregnancy loss after artificial insemination (pig (Bathgate et al. 2008) and bull (Underwood et al. 2009a, 2009b)). However, in this regard, the ram appears to be the exception to the rule as sex-sorting did not reduce fertility of ram spermatozoa when it was used for intrauterine insemination (de Graaf et al. 2009).

\section{Novel sperm surface manipulation methods}

\section{Stabilisation of the sperm surface with cholesterol and other lipids}

Cholesterol efflux from the plasma membrane is one of the recognised responses of spermatozoa (see section 'Physiological alterations of the sperm surface') in a capacitation-supportive medium (Travis \& Kopf 2002, Witte \& Schafer-Somi 2007). While these modifications are thought to be essential for fertilisation (Parinaud et al. 2000), they also increase the fragility of the sperm surface, rendering it more sensitive to handling imposed deterioration (Van Gestel et al. 2005b). Similar to capacitated spermatozoa, frozen-thawed spermatozoa also show some signs of membrane lipid modification such as higher membrane fluidity, partial phospholipid scrambling (Thomas et al. 2006) and loss of polyunsaturated fatty acids and cholesterol (Maldjian et al. 2005, Chakrabarty et al. 2007).
It has long been known that specific vesicle additives can stabilise spermatozoa and protect them from freezethaw damage (Watson 1981, Holt \& North 1988). The addition of certain lipid mixtures, including cholesterol (Moore et al. 2005), appeared to be the best way to prevent deterioration, and more recently, cholesterol-loaded cyclodextrins (CLC; molecules with specific affinity for free sterols (Shadan et al. 2004)) have been used (Moce et al. 2010, Serin et al. 2011). Such approaches led to increased cellular levels of cholesterol by monomeric transfer of these lipids from their carriers and spermatozoa pre-loaded with cholesterol are more stable during freeze-thawing than those that have not been pre-loaded (Moce \& Graham 2006, Aksoy et al. 2010, Moraes et al. 2010, Oliveira et al. 2010). The responsiveness of the surviving cells to in vitro capacitating treatments was questioned but studies in the bull (Purdy \& Graham 2004) and stallion (Spizziri et al. 2010) indicate that CLC-treated spermatozoa remain fertile.

\section{Protection of the sperm surface and DNA by antioxidants}

Several lines of evidence demonstrate that an active, well-balanced and controlled oxidant system regulates capacitation by generating CAMP and tyrosine phosphorylation (O'Flaherty et al. 2006, de Lamirande \& O'Flaherty 2008, de Lamirande \& Lamothe 2009). In line with this, ROS interact with cholesterol, a known mediator of capacitation, at the sperm surface. Brouwers et al. (2011) demonstrated that cholesterol can be oxidised during capacitation and that these oxidation products are preferentially adsorbed by albumin (the cholesterol depletory in IVF media). However, cholesterol oxidation and depletion was not observed in frozen-thawed spermatozoa, and this unique behaviour of cholesterol under different sperm conditions requires further elucidation.

However, uncontrolled ROS production leads to excessive lipid peroxidation, DNA damage and sperm deterioration (Aitken 1995, Aitken \& Curry 2011). Therefore, there appears to be a window of opportunity for capacitation, as spermatozoa go from a nonresponsive to a responsive state by mild and controlled ROS formation. If the responsive (capacitation) state is reached and ROS formation is not stopped, after a certain time period, the same process that initiated capacitation will now cause membrane and DNA deterioration (for review, see Aitken \& Baker (2006) and Storey (2008)). What remains unclear is whether this is a sperm apoptosis phenomenon with specific cell death pathways (for model, see Aitken (2011)) or whether the ROS-imposed peroxidation just exceeds an irreversible limit of membrane dysfunction and chromatin damage. The latter cannot be excluded, as cholesterol oxidation and depletion, as well as DNA 
deterioration, take place far away from the mid-piece, where mitochondrial induced apoptosis is to be expected (Brouwers et al. 2011). Moreover, as spermatozoa are translationally and transcriptionally silent, their chromatin has very specific features that may not be recognised by apoptosis-related DNA ligases of somatic cells.

Regardless of how spermatozoa deteriorate, sperm handling causes prolonged exposure of the cells to light (singlet oxygen formation) and oxygen that can create an oxidative environment and lead to detrimental peroxidative processes (Brouwers \& Gadella 2003, Brouwers et al. 2005). Handling techniques, such as centrifugation (Agarwal et al. 1994, Shekarriz et al. 1995) and cryopreservation (Ball et al. 2001, Chatterjee \& Gagnon 2001), may also reduce the presence and activity of naturally occurring antioxidants and cause spermatozoa to generate ROS (Bilodeau et al. 2000, Marti et al. 2008). Finally, it is well documented that freezing or sex-sorting increases the susceptibility of spermatozoa to ROS damage, even when compared with capacitated spermatozoa (Salamon \& Maxwell 1995a, Brouwers \& Gadella 2003, Neild et al. 2005, Leahy et al. 2010a).

For these reasons, antioxidant supplementation has been shown to increase the oxidative resistance of flowsorted (Klinc \& Rath 2007, Klinc et al. 2007, Leahy et al. 2010a), liquid-stored (Maxwell \& Stojanov 1996, Aurich et al. 1997, Johnson et al. 2000, Aurich 2008) and frozen-thawed spermatozoa (Branco et al. 2010, Bucak et al. 2010, Malo et al. 2010, Kalthur et al. 2011). Such optimisation of processing techniques has resulted in increased fertility rates in numerous species, particularly with regard to liquid stored semen. However, if achieving the correct balance between oxidation and reduction were so simple, then antioxidants would be routinely included in all semen diluents. The reason this does not occur is that uncontrolled antioxidant treatment can also be detrimental, as cells generally function in a reduced state (termed the 'anti-oxidant paradox'; reviewed by Henkel (2011)). For instance, capacitation is reduction dependent and it is not clear whether excessive anti-oxidant protection during sperm handling renders the surviving cells responsive to a capacitation-inducing environment. It is probable that capacitation-specific oxysterol formation and depletion are hindered by anti-oxidants (see Fig. 3). This is also valid for the bicarbonate-dependent adenylate cyclase/ cAMP/protein kinase $\mathrm{A}$ and tyrosine kinase signalling pathways and thus for the generation of hyperactivated sperm motility.

\section{Stabilisation of the sperm surface with seminal plasma proteins}

Due to the stabilising effect of seminal plasma on the sperm membrane, and its partial or complete removal during processing for freezing or sex-sorting, seminal plasma has naturally been explored as an additive to mediate the detrimental effects of these technologies (see Fig. 3). The presence of seminal plasma during freezing is generally considered to protect the sperm membrane but the effect is more pronounced in certain species. In the ram (Graham 1994, Maxwell et al. 1999, Leahy et al. 2010c) and boar (Suzuki et al. 2002, Hernandez et al. 2007a, Vadnais \& Roberts 2007, 2010, Garcia et al. 2010), inclusion of whole seminal plasma in the freezing regime results in the improvement of a whole host of functional parameters of spermatozoa upon thawing, including the ability to hold the sperm sample in a non-capacitated state.

Addition of seminal plasma as part of the sex-sorting protocol has met with similar success. Early on, it was shown that inclusion of ram or boar seminal plasma in a number of sorting diluents improved the viability and motility of the final product and reduced capacitationlike changes (Maxwell et al. 1996, 1998, Catt et al. 1997, Spinaci et al. 2006) induced by flow-sorting (Maxwell \& Johnson 1997). While seminal plasma is now commonly added to the collection medium (Parrilla et al. 2005), or after concentration of sorted boar spermatozoa (Grossfeld et al. 2005), later studies in the ram were not as conclusive, reporting both beneficial (Leahy et al. 2009) and detrimental effects of seminal plasma on the function of sorted spermatozoa (de Graaf et al. 2007).

Such variations in the response of spermatozoa to seminal plasma are well documented (Katila \& Kareskoski 2006, Maxwell et al. 2007, Muino-Blanco et al. 2008), as both the source and subsequent treatment of seminal plasma and spermatozoa influence the final outcome, and are thought to reflect differences in the relative abundance of beneficial and detrimental seminal factors. The major determinants include donor animal (e.g. good vs poor freezing boars (Hernandez et al. 2007a)), season (Leahy et al. 2010c), sperm fraction utilised (e.g. sperm rich (Saravia et al. 2009), as well as prior processing of seminal plasma (e.g. fractionation of seminal plasma (Ollero et al. 1997)) or sperm samples (e.g. washed vs non-washed (Perez-Pe et al. 2001)). Finally, protocol variations, such as point of addition of seminal plasma (e.g. pre-freeze vs post-freeze) and protein concentration (Leahy et al. 2009, 2010c), affect the response of spermatozoa to seminal plasma.

These variants contribute to the controversial effect of seminal plasma on field fertility. Supplementation of seminal plasma to frozen-thawed boar spermatozoa has been reported to improve farrowing rates (Okazaki et al. 2009) and litter size (Garcia et al. 2010). While other studies have found no effects on fertility (Abad et al. 2007a) or on the establishment of an oviductal sperm reservoir (Abad et al. 2007b). The situation is similar in the ram where cervical insemination of frozen-thawed sorted or non-sorted ram spermatozoa has been reported to improve or 


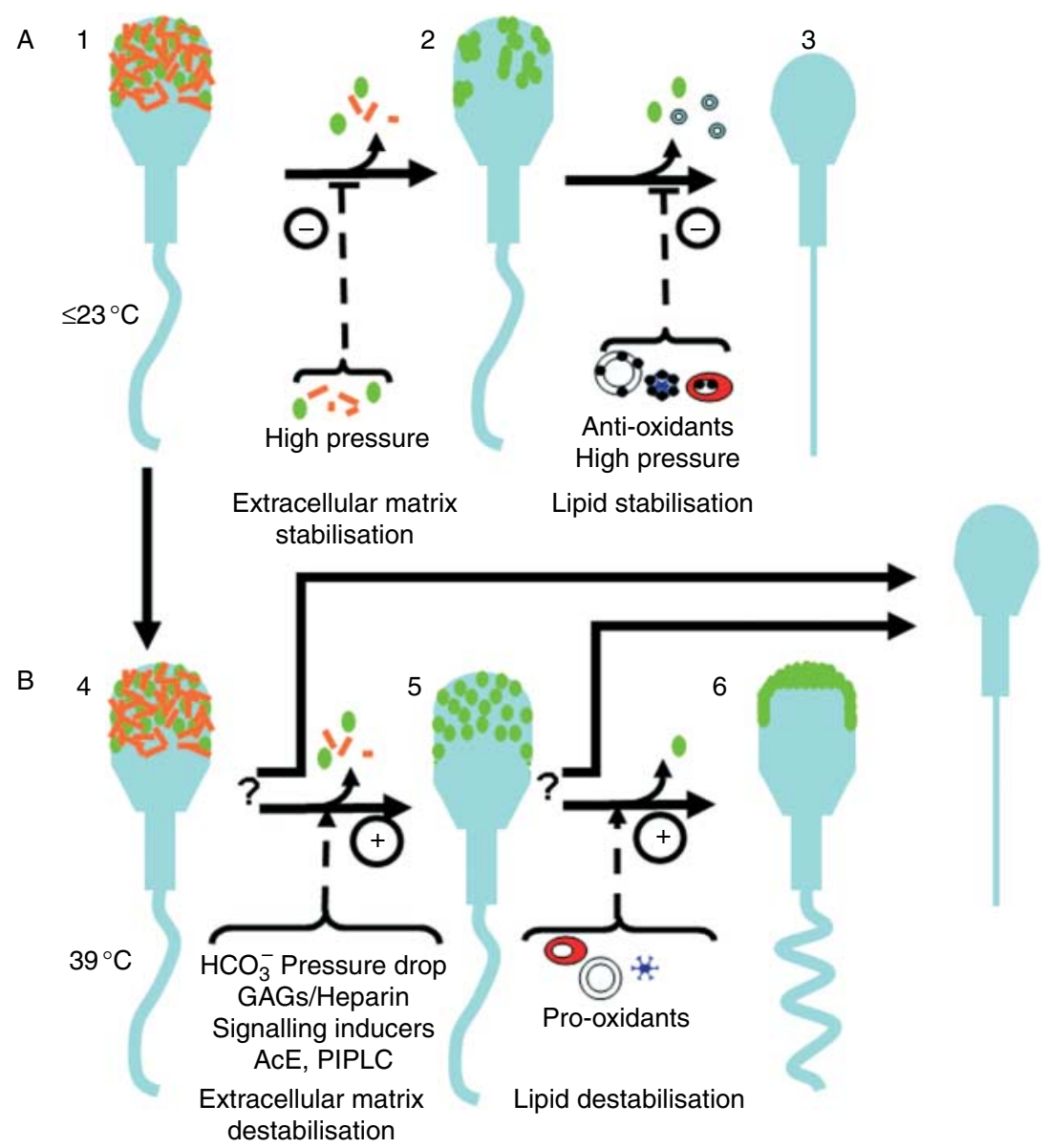

Figure 3 Effect of surface stabilising methods on the fertilising ability of spermatozoa. (A) Methods to stabilise the spermatozoa during handling. Without such approaches, a greater proportion of cells will deteriorate during processing (membrane deterioration depicted here). These methods aim to keep the sperm surface in a stable, non-capacitated state (resembling that of ejaculated spermatozoa) during handling. To achieve this, physical and osmotic stressors must be minimised (see also Fig. 2B and C). At ejaculation, seminal plasma proteins (in orange) bind to the membrane and stabilise it but it is not known whether they replace decapacitation factors removed from the sperm surface during handling, or if their association physically inhibits the removal process (1). The application of high hydrostatic pressure (HHP) may result in firmer attachment of seminal plasma factors to the sperm surface (2), providing additional stability to the sperm cells, or result in higher adaptation rates to a changing in vitro environment (e.g. temperature, $\mathrm{pH}$, osmolytes and pressure). Cholesterol oxidation can be inhibited by the addition of anti-oxidants and/or albumin (in purple) and cholesterol efflux by inclusion of cyclodextrin (in red) or vesicles (in white) that are preloaded with saturated amounts of cholesterol (in black) or other lipids (3). (B) Methods to remove these stabilising factors in order to achieve a functionally capacitated spermatozoon capable of fertilising the oocyte. It is debatable whether subsequent destabilisation of processed spermatozoa will allow them to enter a true capacitated state (4). IVF treatments that are currently employed (5) include bicarbonate (stimulates adenylate cyclase/cAMP/protein kinase A and tyrosine kinase signalling pathways) heparin (enhances stripping of the sperm surface) and fatty acid-free albumin (depletes cholesterol). Novel stimulation methods include cholesterol-accepting vesicles (in white) or cholesterol-free cyclodextrin (in red) or the use of certain pro-oxidants (6) (Rodriguez \& Beconi 2009, Rodriguez et al. 2011). For further details and references, see section 'Novel sperm surface manipulation methods'.

have no effect on field fertility (Maxwell et al. 1999, El-Hajj Ghaoui et al. 2007, O'Meara et al. 2007, Leahy et al. 2010b).

This variability could be reduced if the exact components responsible for the beneficial or detrimental effects of seminal plasma were identified. Separation and characterisation of bull seminal plasma proteins have greatly expanded knowledge on the signalling pathways of capacitation and the protective action of extender components (for review, see Manjunath et al. (2007)). The main molecules of functional dominance in bull seminal plasma are BSP proteins of the fibronectin type II family, which bind tightly to choline phospholipids on the sperm membrane upon ejaculation (Manjunath et al. 2009). This initially stabilises the sperm membrane but extended association causes efflux of cholesterol in a dose- and time-dependent manner (Therien et al. 1998, 1999). As BSP proteins can also bind high-density lipoprotein and heparin-like glycosaminoglycans (Gwathmey et al. 2003, 2006) - known capacitation factors in follicular and oviductal fluids - in vivo, they may act as regulators of capacitation (Lane et al. 1999). However, their presence for extended periods in vitro is not beneficial to sperm survival. Fortunately, the 
common use of egg yolk and skim milk in cryoprotective diluents appears to have unintentionally masked this detrimental effect, as low-density lipoproteins and casein micelles present in these diluents preferentially bind BSP proteins, reducing the number available to bind to the sperm membrane (Manjunath et al. 2002).

In the boar, the effect of heparin-binding proteins is not as well documented and has been reported to have both positive and negative effects on sperm function, particularly in relation to the inhibition or stimulation of capacitation. Vadnais \& Roberts (2010) reported that a heparin-binding fraction of boar seminal plasma, consisting of three spermadhesins (AQN-3, AQN-1, $\mathrm{AWN}$ ) and the BSP protein, $\mathrm{pB} 1$, inhibited in vitro capacitation and cooling-induced capacitation-like changes (Vadnais \& Roberts 2010). This agrees with early structural studies, showing that non-aggregated forms of $\mathrm{AWN}-1$ and $\mathrm{AQN}-3$ are able to bind directly to membrane lipids (Dostalova et al. 1995) and are partly released from the sperm surface upon capacitation (Sanz et al. 1993, Dostalova et al. 1994, Calvete et al. 1997), suggesting they act as decapacitation factors. However, AQN-3 has also been shown to be involved in the binding of capacitated boar spermatozoa to the zona pellucida (van Gestel et al. 2007), indicating that release of seminal plasma factors from the sperm surface is not a straightforward process. Moreover, the heparin-binding BSP protein, pB1, has also been shown to stimulate capacitation of epididymal boar spermatozoa by inducing cholesterol and phospholipid efflux from the sperm membrane (Lusignan et al. 2007), which has been extensively documented with bull BSP proteins. Incubation of highly diluted boar spermatozoa (extended to a level that mimicked sex-sorting: $0.3-1 \times 10^{6}$ sperm $/ \mathrm{ml}$ ) with heparin-binding proteins was detrimental to in vitro sperm function (Centurion et al. 2003), causing a timeand dose-dependent decrease in the motility, viability and mitochondrial integrity of spermatozoa. Nonheparin-binding proteins showed the opposite effect (Caballero et al. 2006) and the protective effect was largely afforded by the PSP-I/PSP-II heterodimer. Subsequent investigation narrowed down the protective effect to the peptidic fragment of the PSP-II subunit (Garcia et al. 2006), suggesting that a simple sperm preserver could potentially be commercially synthesised containing only this fragment (Caballero et al. 2008). Immunolocalisation studies have revealed that the PSP-I/ PSP-II heterodimer is mainly located on the acrosomal region of boar spermatozoa and that this association holds the cell in a time-limited non-capacitated state by maintaining low intracellular calcium levels (Caballero et al. 2009). After long-term incubation, the heterodimer redistributes to the post-acrosomal region. Interestingly, heparin-binding proteins show the opposite pattern, and this redistribution has also been related to capacitation status (Dapino et al. 2009).
These somewhat contradictory results highlight the importance of prior treatment of spermatozoa on the subsequent effect of seminal plasma protein supplementation. The aforementioned studies investigated epidiymal, ejaculated and highly diluted boar spermatozoa. As it is thought that pro-capacitation factors only have effects on the sperm surface after appropriate removal of other coating factors, it is probable that the differing effects reported for boar heparin-binding proteins are due to differences in the extracellular matrix of these sperm types. However, these processing differences do not explain the interesting variation between species when supplemented with BSP proteins.

As outlined above, seminal plasma proteins are well known to protect ram spermatozoa from cold shock (cooled or frozen in the absence of cryoprotectants) or during routine freezing (for review, see Maxwell et al. (2007) and Muino-Blanco et al. (2008)). The main protective components were reported to be a $14 \mathrm{kDa}$ BSP protein, which was shown to prevent (Barrios et al. 2005) or reverse (Barrios et al. 2000) cold shock damage. The reason why these proteins do not appear to destabilise the ram sperm membrane, as shown in the bull, is not clear but may be due to differences in stimulation of capacitation. Colas et al. (2008) showed that ram spermatozoa are relatively insensitive to cholesterol-depleting reagents (e.g. albumin) that provoke tyrosine phosphorylation and capacitation in other species.

These multiple influences explain why, despite having known about the decapacitation effect of seminal plasma (Chang 1957) soon after discovery of the process itself (Austin 1952), we have failed to reliably exploit this natural phenomenon to protect spermatozoa during processing. Nevertheless, dissection of the effects of specific proteins has provided novel insights into the capacitation pathway and the function of previously unknown cryoprotective diluents (e.g. milk and egg yolk) and has also produced promising protective factors (e.g. PSP-II) for inclusion in well-defined sperm handling protocols.

\section{The use of stress to improve stress tolerance}

It is well recognised that in vitro manipulations have a detrimental impact on sperm quality, and new insights in this area have been reviewed in the current manuscript. However, this long-held dogma is challenged by a new evidence demonstrating that exposure to carefully controlled levels of stress can be beneficial to sperm survival. The aim of this novel manipulation method is to trigger the gametes' survival mechanisms by subjecting them to sub-lethal levels of stress (pre-stress), which then improves their resistance to subsequent challenges (e.g. storage, sex-sorting, embryo culture, etc.). The technique has been performed on various cell types (spermatozoa, oocytes, embryos and stem cells) using numerous 
stressors (e.g. hydrostatic pressure, osmotic, heat and oxidation). The preferred method is high hydrostatic pressure (HHP), as it can be applied with the aid of a programmable device in an instantaneous, uniform and consistent manner (Pribenszky et al. 2010). Optimisation of pressure, temperature and exposure time has produced improvements in the quality and fertility of fresh, chilled and frozen-thawed bull and boar spermatozoa (reviewed by Callesen (2010), Pribenszky et al. (2010) and Pribenszky \& Vajta (2011)). However, the mechanism by which HHP treatment confers increased resistance to stress is not known. It has been suggested that it may result from the production of chaperone proteins (Pribenszky \& Vajta 2011), but no differences between HHP-treated and non-treated boar spermatozoa have been observed (Huang et al. 2009) and this explanation is controversial as the biosynthetic capabilities of spermatozoa are limited.

HHP is known to alter cell morphology, membrane fluidity, protein conformation and protein interactions (McCarthy \& Grigera 2006). These effects are considered reversible at the levels applied during HHP treatment but it is possible that these changes alter the permeability of the sperm membrane to penetrating cryoprotectants (e.g. glycerol) and cause a quickening of diffusion processes during freezing, which would reduce the length of time the cells are exposed to an adverse osmotic environment. Alternatively, HHP treatment may result in firmer attachment of extracellular material to the sperm surface (e.g. egg yolk and seminal plasma proteins) providing additional stability to the sperm cell. In fact, spermadhesins (AWN) have been reported to be of greater abundance on the membrane of HHPtreated boar spermatozoa compared to those without HHP treatment (Huang et al. 2009). Such a finding would have important implications for the concurrent use of HHP treatment with other surface-stabilising components discussed in the current review, and its mechanism of action requires further attention.

\section{General conclusion}

Modern sperm surface stabilising strategies (see section 'Novel sperm surface manipulation methods') can partly prevent or reverse the detrimental effects of sperm handling (see section 'Sperm surface alterations during sperm handling'). Further developments in this area would benefit from clarification of the differences between physiological sperm capacitation (see section 'Physiological alterations of the sperm surface') and handling-induced capacitation-like changes. It has already been shown that protein tyrosine phosphorylation patterns may differ (Green \& Watson 2001), and as we gain further insight into the capacitation process, it is becoming unlikely that other intricate stimulation mechanisms such as cholesterol depletion, ROS-induced specific signalling of spermatozoa and removal of seminal plasma proteins from the sperm surface occur in a controlled manner during 'capacitation' induced by sperm handling as they do during physiological capacitation.

It also remains to be seen whether these stabilising components render spermatozoa unresponsive to subsequent incubation in a capacitation-supportive environment. Strategies to stimulate capacitation, through the depletion of cholesterol from the sperm membrane, or the triggering of capacitation-specific sperm signalling pathways, are emerging and have been shown to increase the success of IVF in rodents (Takeo et al. 2008, Seita et al. 2009). However, the hypothesis that oxidants (especially peroxynitrite) could prepare spermatozoa for fertilisation has not been tested, despite their ability to initiate capacitation (Rodriguez \& Beconi 2009, Rodriguez et al. 2011). Such studies may shed light on achieving an optimal balance between antioxidant inclusion, to prevent sperm damage during handling and pro-oxidant concentration to trigger capacitation when required.

The recent observations and hypotheses described in this review provide further insight into the dogma of sperm capacitation and handling-induced sperm damage. Overall, the studies show the following: i) in order to survive handling, spermatozoa need to be stabilised at their surface, ii) physiological capacitation is a very specific surface destabilisation event involving very subtle and intricate processes and iii) it is possible that we override such processes during in vitro handling of spermatozoa. Careful balancing of strategies to stabilise the sperm surface during handling to prevent premature deterioration, and destabilisation of the sperm surface in the correct time and place, are crucial factors in obtaining the desired ART outcome.

\section{Declaration of interest}

The authors declare that there is no conflict of interest that could be perceived as prejudicing the impartiality of the research reported.

\section{Funding}

This research did not receive any specific grant from any funding agency in the public, commercial or not-for-profit sector.

\section{Acknowledgements}

The authors wish to thank Prof. WMC Maxwell for critical reading of the manuscript.

\section{References}

Abad M, Garcia JC, Sprecher DJ, Cassar G, Friendship RM, Buhr MM \& Kirkwood RN 2007a Effect of insemination-ovulation interval and 
addition of seminal plasma on sow fertility to insemination of cryopreserved sperm. Reproduction in Domestic Animals 42 418-422. (doi:10.1111/j.1439-0531.2006.00801.x)

Abad M, Sprecher DJ, Ross P, Friendship RM \& Kirkwood RN 2007b Effect of sperm cryopreservation and supplementing semen doses with seminal plasma on the establishment of a sperm reservoir in gilts. Reproduction in Domestic Animals 42 149-152. (doi:10.1111/j.14390531.2006.00744.x)

Adeoya-Osiguwa SA \& Fraser LR 1996 Evidence for $\mathrm{Ca}^{2+}$-dependent ATPase activity, stimulated by decapacitation factor and calmodulin, in mouse sperm. Molecular Reproduction and Development 44 111-120. (doi:10. 1002/(SICl)1098-2795(199605)44:1 <111::AID-MRD13>3.0.CO;2-7)

Agarwal A, Ikemoto I \& Loughlin KR 1994 Effect of sperm washing on levels of reactive oxygen species in semen. Archives of Andrology 33 157-162. (doi:10.3109/01485019408987819)

Aitken RJ 1995 Free radicals, lipid peroxidation and sperm function. Reproduction, Fertility, and Development 7 659-668. (doi:10.1071/ RD9950659)

Aitken RJ 2011 The capacitation-apoptosis highway: oxysterols and mammalian sperm function. Biology of Reproduction 85 9-12. (doi:10.1095/ biolreprod.111.092528)

Aitken RJ \& Baker MA 2006 Oxidative stress, sperm survival and fertility control. Molecular and Cellular Endocrinology 250 66-69. (doi:10. 1016/j.mce.2005.12.026)

Aitken RJ \& Curry BJ 2011 Redox regulation of human sperm function: from the physiological control of sperm capacitation to the etiology of infertility and DNA damage in the germ line. Antioxidants \& Redox Signaling 14 367-381. (doi:10.1089/ars.2010.3186)

Aitken RJ, Wingate JK, De Iuliis GN \& McLaughlin EA 2007 Analysis of lipid peroxidation in human spermatozoa using BODIPY C-11. Molecular Human Reproduction 13 203-211. (doi:10.1093/molehr/ gal119)

Aksoy M, Akman O, Lehimcioglu NC \& Erdem H 2010 Cholesterol-loaded cyclodextrin enhances osmotic tolerance and inhibits the acrosome reaction in rabbit spermatozoa. Animal Reproduction Science $\mathbf{1 2 0}$ 166-172. (doi:10.1016/j.anireprosci.2010.02.014)

Amann R \& Hammerstedt R 1993 In vitro evaluation of sperm quality: an opinion. Journal of Andrology 14 397-406.

Anderson RGW 1998 The caveolae membrane system. Annual Review of Biochemistry 67 199-225. (doi:10.1146/annurev.biochem.67.1.199)

Arnoult C, Zeng Y \& Florman HM 1996 ZP3-dependent activation of sperm cation channels regulates acrosomal secretion during mammalian fertilization. Journal of Cell Biology 134 637-645. (doi:10.1083/jcb. 134.3.637)

Asadpour R, Alavi-Shoushtari SM, Rezaii SA \& Ansari MHK 2007 SDS-polyacrylamide gel electrophoresis of buffalo bulls seminal plasma proteins and their relation with semen freezability. Animal Reproduction Science 102 308-313. (doi:10.1016/j.anireprosci.2007.03.003)

Aurich C 2008 Recent advances in cooled-semen technology. Animal Reproduction Science 107 268-275. (doi:10.1016/j.anireprosci.2008. 04.015)

Aurich JE, Schonherr U, Hoppe H \& Aurich C 1997 Effects of antioxidants on motility and membrane integrity of chilled-stored stallion semen. Theriogenology 48 185-192. (doi:10.1016/S0093-691X(97)84066-6)

Austin CR 1952 The capacitation of the mammalian sperm. Nature $\mathbf{1 7 0}$ 326. (doi:10.1038/170326a)

Bagchi A, Woods EJ \& Critser JK 2008 Cryopreservation and vitrification: recent advances in fertility preservation technologies. Expert Review of Medical Devices 5 359-370. (doi:10.1586/17434440.5.3.359)

Bailey JL, Bilodeau JF \& Cormier N 2000 Semen cryopreservation in domestic animals: a damaging and capacitating phenomenon. Journal of Andrology 21 1-7.

Bailey JL, Lessard C, Jacques J, Breque C, Dobrinski I, Zeng WX \& Galantino-Homer HL 2008 Cryopreservation of boar semen and its future importance to the industry. Theriogenology 70 1251-1259. (doi:10.1016/j.theriogenology.2008.06.014)

Baker MA, Witherdin R, Hetherington L, Cunningham-Smith K \& Aitken RJ 2005 Identification of post-translational modifications that occur during sperm maturation using difference in two-dimensional gel electrophoresis. Proteomics 5 1003-1012. (doi:10.1002/pmic. 200401100)
Ball BA, Vo AT \& Baumber J 2001 Generation of reactive oxygen species by equine spermatozoa. American Journal of Veterinary Research 62 508-515. (doi:10.2460/ajvr.2001.62.508)

Barrios B, Perez-Pe R, Gallego M, Tato A, Osada J, Muino-Blanco T \& Cebrian-Perez JA 2000 Seminal plasma proteins revert the cold-shock damage on ram sperm membrane. Biology of Reproduction 63 1531-1537. (doi:10.1095/biolreprod63.5.1531)

Barrios B, Fernandez-Juan M, Muino-Blanco T \& Cebrian-Perez JA 2005 Immunocytochemical localization and biochemical characterization of two seminal plasma proteins that protect ram spermatozoa against cold shock. Journal of Andrology 26 539-549. (doi:10.2164/jandrol.04172)

Bathgate R 2008 Functional integrity of sex-sorted, frozen-thawed boar sperm and its potential for artificial insemination. Theriogenology $\mathbf{7 0}$ 1234-1241. (doi:10.1016/j.theriogenology.2008.06.009)

Bathgate R, Grossfeld R, Susetio D, Ruckholdt M, Heasman K, Rath D, Evans G \& Maxwell WMC 2008 Early pregnancy loss in sows after low dose, deep uterine artificial insemination with sex-sorted, frozen-thawed sperm. Animal Reproduction Science 104 440-444. (doi:10.1016/j. anireprosci.2007.06.028)

Bedford JM 2004 Enigmas of mammalian gamete form and function. Biological Reviews 79 429-460. (doi:10.1017/S146479310300633X)

Bedford JM \& Chang MC 1962 Removal of decapacitation factor from seminal plasma by high-speed centrifugation. American Journal of Physiology 202 179-187.

Belleannee C, Labas V, Teixeira-Gomes AP, Gatti JL, Dacheux JL \& Dacheux F 2011 Identification of luminal and secreted proteins in bull epididymis. Journal of Proteomics 74 59-78. (doi:10.1016/j.jprot.2010. 07.013)

Bergeron A, Crete MH, Brindle Y \& Manjunath P 2004 Low-density lipoprotein fraction from hen's egg yolk decreases the binding of the major proteins of bovine seminal plasma to sperm and prevents lipid efflux from the sperm membrane. Biology of Reproduction 70 708-717. (doi:10.1095/biolreprod.103.022996)

Bilodeau JF, Chatterjee S, Sirard MA \& Gagnon C 2000 Levels of antioxidant defenses are decreased in bovine spermatozoa after a cycle of freezing and thawing. Molecular Reproduction and Development 55 282-288. (doi:10.1002/(SICl)1098-2795(200003)55:3<282:: AID-MRD6 > 3.0.CO;2-7)

Branco CS, Garcez ME, Pasqualotto FF, Erdtman B \& Salvador M 2010 Resveratrol and ascorbic acid prevent DNA damage induced by cryopreservation in human semen. Cryobiology 60 235-237. (doi:10. 1016/j.cryobiol.2009.10.012)

Bravo MM, Aparicio IM, Garcia-Herreros M, Gil MC, Pena FJ \& GarciaMarin LJ 2005 Changes in tyrosine phosphorylation associated with true capacitation and capacitation-like state in boar spermatozoa. Molecular Reproduction and Development 71 88-96. (doi:10.1002/mrd.20286)

Breitbart H 2002 Role and regulation of intracellular calcium in acrosomal exocytosis. Journal of Reproductive Immunology 53 151-159. (doi:10. 1016/S0165-0378(01)00085-7)

Brouwers J \& Gadella BM 2003 In situ detection and localization of lipid peroxidation in individual bovine sperm cells. Free Radical Biology \& Medicine 35 1382-1391. (doi:10.1016/j.freeradbiomed.2003.08.010)

Brouwers JF, Silva PFN \& Gadella BM 2005 New assays for detection and localization of endogenous lipid peroxidation products in living boar sperm after BTS dilution or after freeze-thawing. Theriogenology 63 458-469. (doi:10.1016/j.theriogenology.2004.09.046)

Brouwers JF, Boerke A, Silva PFN, Garcia-Gil N, van Gestel RA, Helms JB, van de Lest CHA \& Gadella BM 2011 Mass spectrometric detection of cholesterol oxidation in bovine sperm. Biology of Reproduction $\mathbf{8 5}$ 128-136. (doi:10.1095/biolreprod.111.091207)

Brussow KP, Ratky J \& Rodriguez-Martinez H 2008 Fertilization and early embryonic development in the porcine fallopian tube. Reproduction in Domestic Animals 43 245-251. (doi:10.1111/j.1439-0531.2008. 01169.x)

Bucak MN, Tuncer PB, Sariozkan S, Baspinar N, Taspinar M, Coyan K, Bilgili A, Akalin PP, Buyukleblebici S, Aydos S et al. 2010 Effects of antioxidants on post-thawed bovine sperm and oxidative stress parameters: antioxidants protect DNA integrity against cryodamage. Cryobiology 61 248-253. (doi:10.1016/j.cryobiol.2010.09.001)

Buhr MM, Curtis EF \& Kakuda NS 1994 Composition and behavior of head membrane-lipids of fresh and cryopreserved boar sperm. Cryobiology 31 224-238. (doi:10.1006/cryo.1994.1028) 
Busso D, Cohen DJ, Maidera JA, Dernatteis A \& Cuasnicu PS 2007 A novel function for CRISP1 in rodent fertilization: involvement in sperm-zona pellucida interaction. Biology of Reproduction 77 848-854. (doi:10. 1095/biolreprod.107.061788)

Caballero I, Vazquez JM, Garcia EM, Roca J, Martinez EA, Calvete JJ, Sanz L, Ekwall H \& Rodriguez-Martinez H 2006 Immunolocalization and possible functional role of PSP-I/PSP-II heterodimer in highly extended boar spermatozoa. Journal of Andrology 27 766-773. (doi:10.2164/jandrol.106.000539)

Caballero I, Vazquez JM, Garcia EM, Parrilla I, Roca J, Calvete JJ, Sanz L \& Martinez EA 2008 Major proteins of boar seminal plasma as a tool for biotechnological preservation of spermatozoa. Theriogenology $\mathbf{7 0}$ 1352-1355. (doi:10.1016/j.theriogenology.2008.07.013)

Caballero I, Vazquez JM, Mayor GM, Alminana C, Calvete JJ, Sanz L, Roca J \& Martinez EA 2009 PSP-I/PSP-II spermadhesin exert a decapacitation effect on highly extended boar spermatozoa. International Journal of Andrology 32 505-513. (doi:10.1111/j.1365-2605. 2008.00887.x)

Callesen H 2010 Challenge testing of gametes to enhance their viability. Reproduction, Fertility, and Development 22 40-46. (doi:10.1071/ RD09213)

Calvete JJ, Raida M, Gentzel M, Urbanke C, Sanz L \& TopferPetersen E 1997 Elation and characterization of heparin- and phosphorylcholinebinding proteins of boar and stallion seminal plasma. Primary structure of porcine pB1. FEBS Letters 407 201-206. (doi:10.1016/S00145793(97)00344-X)

Casas I, Sancho S, Briz A, Pinart E, Bussalleu E, Yeste M \& Bonet S 2009 Freezability prediction of boar ejaculates assessed by functional sperm parameters and sperm proteins. Theriogenology 72 930-948. (doi:10.1016/j.theriogenology.2009.07.001)

Casas I, Sancho S, Ballester J, Briz M, Pinart E, Bussalleu E, Yeste M, Fabrega A, Rodriguez-Gil JE \& Bonet S 2010 The HSP90AA1 sperm content and the prediction of the boar ejaculate freezability. Theriogenology 74 940-950. (doi:10.1016/j.theriogenology. 2010.04.021)

Catt SL, O'Brien JK, Maxwell WMC \& Evans G 1997 Assessment of ram and boar spermatozoa during cell-sorting by flow cytometry. Reproduction in Domestic Animals 32 251-258. (doi:10.1111/j.1439-0531.1997. tb01290.x)

Centurion F, Vazquez JM, Calvete JJ, Roca J, Sanz L, Parrilla I, Garcia EM \& Martinez EA 2003 Influence of porcine spermadhesins on the susceptibility of boar spermatozoa to high dilution. Biology of Reproduction 69 640-646. (doi:10.1095/biolreprod.103.016527)

Chakrabarty J, Banerjee D, Pal D, De J, Ghosh A \& Majumder GC 2007 Shedding off specific lipid constituents from sperm cell membrane during cryopreservation. Cryobiology 54 27-35. (doi:10.1016/j.cryobiol. 2006.10.191)

Chang MC 1957 A detrimental effect of seminal plasma on the fertilizing capacity of sperm. Nature 179 258-259. (doi:10.1038/179258a0)

Chatterjee S \& Gagnon C 2001 Production of reactive oxygen species by spermatozoa undergoing cooling, freezing, and thawing. Molecular Reproduction and Development 59 451-458. (doi:10.1002/mrd.1052)

Chaveiro A, Liu J, Engel B, Critser JK \& Woelders H 2006 Significant variability among bulls in the sperm membrane permeability for water and glycerol: possible implications for semen freezing protocols for individual males. Cryobiology 53 349-359. (doi:10.1016/j.cryobiol. 2006.08.005)

Colas C, James P, Howes L, Jones R, Cebrian-Perez JA \& Muino-Blanco T 2008 Cyclic-AMP initiates protein tyrosine phosphorylation independent of cholesterol efflux during ram sperm capacitation. Reproduction, Fertility, and Development 20 649-658. (doi:10.1071/RD08023)

Copland SD, Murphy AA \& Shur BD 2009 The mouse gamete adhesin, SED1, is expressed on the surface of acrosome-intact human sperm. Fertility and Sterility 92 2014-2019. (doi:10.1016/j.fertnstert.2008.09. 004)

Cormier N \& Bailey JL 2003 A differential mechanism is involved during heparin- and cryopreservation-induced capacitation of bovine spermatozoa. Biology of Reproduction 69 177-185. (doi:10.1095/biolreprod. 102.011056)

Coy P, Canovas S, Mondejar I, Saavedra MD, Romar R, Grullon L, Matas C \& Aviles M 2008 Oviduct-specific glycoprotein and heparin modulate sperm-zona pellucida interaction during fertilization and contribute to the control of polyspermy. PNAS 105 15809-15814. (doi:10.1073/pnas. 0804422105)

Cross N 2004 Reorganization of lipid rafts during capacitation of human sperm. Biology of Reproduction 71 1367-1373. (doi:10.1095/biolreprod.104.030502)

Dacheux JL, Dacheux F \& Paquignon M 1989 Changes in sperm surface membrane and luminal protein fluid content during epidiymal content during epididymal transit in the boar. Biology of Reproduction $\mathbf{4 0}$ 635-651. (doi:10.1095/biolreprod40.3.635)

Dacheux JL, Castella S, Gatti JL \& Dacheux F 2005 Epididymal cell secretory activities and the role of proteins in boar sperm maturation. Theriogenology 63 319-341. (doi:10.1016/j.theriogenology.2004. 09.015)

Dacheux JL, Belleannee C, Jones R, Labas V, Belghazi M, Guyonnet B, Druart X, Gatti JL \& Dacheux F 2009 Mammalian epididymal proteome. Molecular and Cellular Endocrinology 306 45-50. (doi:10.1016/j.mce. 2009.03.007)

Dapino DG, Teijeiro JM, Cabada MO \& Marini PE 2009 Dynamics of heparin-binding proteins on boar sperm. Animal Reproduction Science 116 308-317. (doi:10.1016/j.anireprosci.2009.02.018)

Da Ros VG, Maldera JA, Willis WD, Cohen DJ, Goulding EH, Gelman DM, Rubinstein M, Eddy EM \& Cuasnicu PS 2008 Impaired sperm fertilizing ability in mice lacking cysteine-rich secretory protein 1 (CRISP1). Developmental Biology 320 12-18. (doi:10.1016/j.ydbio.2008.03.015)

De Leeuw FE, Chen H-C, Colenbrander B \& Verkleij AJ 1990 Cold-induced ultrastructural changes in bull and boar sperm plasma membranes. Cryobiology 27 171-183. (doi:10.1016/0011-2240(90)90009-S)

Devireddy RV, Fahrig B, Godke RA \& Leibo SP 2004 Subzero water transport characteristics of boar spermatozoa confirm observed optimal cooling rates. Molecular Reproduction and Development 67 446-457. (doi:10.1002/mrd.20041)

Dostalova Z, Calvete JJ, Sanz L, Hettel C, Riedel D, Schoneck C, Einspanier R \& Topferpetersen E 1994 Immunolocalization and quantitation of acidic seminal fluid protein (Asfp) in ejaculated, swimup, and capacitated bull spermatozoa. Biological Chemistry HoppeSeyler 375 457-461. (doi:10.1515/bchm3.1994.375.7.457)

Dostalova Z, Calvete J \& Topfer-Petersen E 1995 Interaction of nonaggregated boar AWN-1 and AQN-3 with phospholipid matrices. A model for coating of spermadhesins to the sperm surface. Biological Chemistry Hoppe-Seyler 376 237-242. (doi:10.1515/bchm3.1995.376. 4.237)

Drobnis EZ, Crowe LM, Berger T, Anchordoguy TJ, Overstreet JW \& Crowe JH 1993 Cold shock damage is due to lipid phase transitions in cell membranes: a demonstration using sperm as a model. Journal of Experimental Zoology 265 432-437. (doi:10.1002/jez.1402650413)

Druart X, Gatti JL, Huet S, Dacheu JL \& Humblot P 2009 Hypotonic resistance of boar spermatozoa: sperm subpopulations and relationship with epididymal maturation and fertility. Reproduction 137 205-213. (doi:10.1530/REP-08-0225)

El-Hajj Ghaoui R, Thomson PC, Leahy T, Evans G \& Maxwell WMC 2007 Autologous whole ram seminal plasma and its vesicle-free fraction improve motility characteristics and membrane status but not in vivo fertility of frozen-thawed ram spermatozoa. Reproduction in Domestic Animals 42 541-549. (doi:10.1111/j.1439-0531.2006.00819.x)

Elliott M \& Higgins JA 1983 Capacitation and the acrosome reaction in guinea pig spermatozoa increase the availability of surface aminophospholipids for labeling by trinitrobenzene sulfonate. Cell Biology International Reports 7 1091-1096. (doi:10.1016/0309-1651 (83)90015-2)

Ensslin MA \& Shur BD 2003 Identification of mouse sperm SED1, a bimotif EGF repeat and discoidin-domain protein involved in sperm-egg binding. Cell 114 405-417. (doi:10.1016/S0092-8674(03)00643-3)

Ensslin M, Vogel T, Calvete JJ, Thole HH, Schmidtke J, Matsuda T \& TopferPetersen E 1998 Molecular cloning and characterization of P47, a novel boar sperm-associated zona pellucida-binding protein homologous to a family of mammalian secretory proteins. Biology of Reproduction $\mathbf{5 8}$ 1057-1064. (doi:10.1095/biolreprod58.4.1057)

Evans J 2001 Fertilin beta and other adams as intergrin ligand: insights into cell adhesion and fertilization. Bioessays 23 628-639. (doi:10.1002/ bies.1088) 
Fariello RM, Del Giudice PT, Spaine DM, Fraietta R, Bertolla RP \& Cedenho AP 2009 Effect of leukocytospermia and processing by discontinuous density gradient on sperm nuclear DNA fragmentation and mitochondrial activity. Journal of Assisted Reproduction and Genetics 26 151-157. (doi:10.1007/s10815-008-9288-0)

Fazeli A, Duncan AE, Watson PF \& Holt WV 1999 Sperm-oviduct interaction: induction of capacitation and preferential binding of uncapacitated spermatozoa to oviductal epithelial cells in porcine species. Biology of Reproduction 60 879-886. (doi:10.1095/biolreprod60.4.879)

Flesch FM \& Gadella BM 2000 Dynamics of the mammalian sperm plasma membrane in the process of fertilization. Biochimica et Biophysica Acta 1469 197-235. (doi:10.1016/S0304-4157(00)00018-6)

Flesch FM, Brouwers J, Nievelstein P, Verkleij AJ, van Golde LMG, Colenbrander B \& Gadella BM 2001 Bicarbonate stimulated phospholipid scrambling induces cholesterol redistribution and enables cholesterol depletion in the sperm plasma membrane. Journal of Cell Science 114 3543-3555.

Fouchecourt S, Metayer S, Locatelli A, Dacheux F \& Dacheux JL 2000 Stallion epididymal fluid proteome: qualitative and quantitative characterization; secretion and dynamic changes of major proteins. Biology of Reproduction 62 1790-1803. (doi:10.1095/biolreprod62.6. 1790)

Fraser LR 1984 Mouse sperm capacitation in vitro involves loss of a surfaceassociated inhibitory component. Journal of Reproduction and Fertility 72 373-384. (doi:10.1530/jrf.0.0720373)

Gadella BM 2008 Sperm membrane physiology and relevance for fertilization. Animal Reproduction Science 107 229-236. (doi:10. 1016/j.anireprosci.2008.05.006)

Gadella BM 2010 Interaction of sperm with the zona pellucida during fertilization. Society of Reproduction and Fertility Supplement 67 267-287.

Gadella BM \& Evans JP 2011 Membrane fusions during mammalian fertilization. Advances in Experimental Medicine and Biology 713 65-80. (doi:10.1007/978-94-007-0763-4_5)

Gadella BM \& Harrison RAP 2000 The capacitating agent bicarbonate induces protein kinase A-dependent changes in phospholipid transbilayer behavior in the sperm plasma membrane. Development 127 2407-2420.

Gadella BM \& Visconti PE 2006 Regulation of capacitation. In The Sperm Cell: Production, Maturation, Fertilization, Regeneration, pp 134-169. Eds C De Jonge \& C Barratt. Cambridge: Cambridge University Press.

Gadella BM, Gadella TWJ, Colenbrander B, Vangolde LMG \& Lopescardozo M 1994 Visualization and quantification of glycolipid polarity dynamics in the plasma membrane of the mammalian spermatozoon. Journal of Cell Science 107 2151-2163.

Gadella BM, Lopescardozo M, Vangolde LMG, Colenbrander B \& Gadella TWJ 1995 Glycolipid migration from the apical to the equatorial subdomains of the sperm head plasma membrane precedes the acrosome reaction - evidence for a primary capacitation event in boa spermatozoa. Journal of Cell Science 108 935-946.

Garcia EM, Vazquez JM, Calvete IJ, Sanz L, Caballero I, Parrilla I, Gil MA, Roca J \& Martinez EA 2006 Dissecting the protective effect of the seminal plasma spermadhesin PSP-I/PSP-II on boar sperm functionality. Journal of Andrology 27 434-443. (doi:10.2164/jandrol.05170)

Garcia EM, Vazquez JM, Parrilla I, Calvete JJ, Sanz L, Caballero I, Roca J, Vazquez JL \& Martinez EA 2007 Improving the fertilizing ability of sex sorted boar spermatozoa. Theriogenology 68 771-778. (doi:10.1016/j. theriogenology.2007.06.006)

Garcia JC, Dominguez JC, Pena FJ, Alegre B, Gonzalez R, Castro MJ, Habing GG \& Kirkwood RN 2010 Thawing boar semen in the presence of seminal plasma: effects on sperm quality and fertility. Animal Reproduction Science 119 160-165. (doi:10.1016/j.anireprosci.2009. 11.001)

Garner DL 2001 Sex-sorting mammalian sperm: concept to application in animals. Journal of Andrology 22 519-526.

Garner DL 2006 Flow cytometric sexing of mammalian sperm. Theriogenology 65 943-957. (doi:10.1016/j.theriogenology.2005.09.009)

Gatti JL, Druart X, Guerin Y, Dacheux F \& Dacheux JL 1999 A 105- to 94-kilodalton protein in the epididymal fluids of domestic mammals is angiotensin I converting enzyme (ACE); evidence that sperm are the source of this ACE. Biology of Reproduction 60 937-945. (doi:10.1095/ biolreprod60.4.937)

Gatti JL, Castella S, Dacheux F, Ecroyd H, Metayer S, Thimon V \& Dacheux JL 2004 Post-testicular sperm environment and fertility. Animal Reproduction Science 82-83 321-339. (doi:10.1016/j.anireprosci.2004. 05.011)

van Gestel RA, Brewis IA, Ashton PR, Helms JB, Brouwers JF \& Gadella BM 2005a Capacitation-dependent concentration of lipid rafts in the apical ridge head area of porcine sperm cells. Molecular Human Reproduction 11 583-590. (doi:10.1093/molehr/gah200)

van Gestel RA, Helms JB, Brouwers J \& Gadella BM 2005b Effects of methyl-beta-cyclodextrin-mediated cholesterol depletion in porcine sperm compared to somatic cells. Molecular Reproduction and Development 72 386-395. (doi:10.1002/mrd.20351)

van Gestel RA, Brewis IA, Ashton PR, Brouwers JF \& Gadella BM 2007 Multiple proteins present in purified porcine sperm apical plasma membranes interact with the zona pellucida of the oocyte. Molecular Human Reproduction 13 445-454. (doi:10.1093/molehr/gam030)

Gibbons R, Adeoya-Osiguwa SA \& Fraser LR 2005 A mouse sperm decapacitation factor receptor is phosphatidylethanolamine-binding protein 1. Reproduction 130 497-508. (doi:10.1530/rep.1.00792)

de Graaf SP, Evans G, Maxwell WMC \& O'Brien JK 2006 In vitro characteristics of fresh and frozen-thawed ram spermatozoa after sex sorting and re-freezing. Reproduction, Fertility, and Development 18 867-874. (doi:10.1071/RD06061)

de Graaf SP, Evans G, Gillan L, Guerra MMP, Maxwell WMC \& O'Brien JK 2007 The influence of antioxidant, cholesterol and seminal plasma on the in vitro quality of sorted and non-sorted ram spermatozoa. Theriogenology $67 \quad 217-227 . \quad$ (doi:10.1016/j.theriogenology.2006. 07.008)

de Graaf SP, Beilby K, Underwood SL, Evans G \& Maxwell WMC 2009 Sperm sexing in sheep and cattle: the exception and the rule. Theriogenology 71 89-97. (doi:10.1016/j.theriogenology.2008.09.014)

Graham JK 1994 Effect of seminal plasma on the motility of epididymal and ejaculated spermatozoa of the ram and bull during the cryopreservation process. Theriogenology 41 1151-1162. (doi:10.1016/S0093-691X(05) 80037-8)

Green CE \& Watson PF 2001 Comparison of the capacitation-like state of cooled boar spermatozoa with true capacitation. Reproduction 122 889-898. (doi:10.1530/rep.0.1220889)

Grossfeld R, Klinc P, Sieg B \& Rath D 2005 Production of piglets with sexed semen employing a non-surgical insemination technique. Theriogenology 63 2269-2277. (doi:10.1016/j.theriogenology.2004. 10.004)

Grossfeld R, Sieg B, Struckmann C, Frenzel A, Maxwell WMC \& Rath D 2008 New aspects of boar semen freezing strategies. Theriogenology 70 1225-1233. (doi:10.1016/j.theriogenology.2008.07.017)

Guthrie HD \& Welch GR 2005 Impact of storage prior to cryopreservation on plasma membrane function and fertility of boar sperm. Theriogenology 63 396-410. (doi:10.1016/j.theriogenology.2004.09.020)

Guyonnet B, Marot G, Dacheux JL, Mercat MJ, Schwob S, Jaffrezic F \& Gatti JL 2009 The adult boar testicular and epididymal transcriptomes. BMC Genomics 10 369. (doi:10.1186/1471-2164-10-369)

Gwathmey TM, Ignotz GG \& Suarez SS 2003 PDC-109 (BSP-A1/A2) promotes bull sperm binding to oviductal epithelium in vitro and may be involved in forming the oviductal sperm reservoir. Biology of Reproduction 69 809-815. (doi:10.1095/biolreprod.102.010827)

Gwathmey TM, Ignotz GG, Mueller JL, Manjunath P \& Suarez SS 2006 Bovine seminal plasma proteins PDC-109, BSP-A3, and BSP-30-kDa share functional roles in storing sperm in the oviduct. Biology of Reproduction 75 501-507. (doi:10.1095/biolreprod.106.053306)

Hagiwara M, Choi JH, Devireddy RV, Roberts KP, Wolkers WF, Makhlouf A \& Bischof JC 2009 Cellular biophysics during freezing of rat and mouse sperm predicts post-thaw motility. Biology of Reproduction 81 700-706. (doi:10.1095/biolreprod.109.076075)

Henkel RR 2011 Leukocytes and oxidative stress: dilemma for sperm function and male fertility. Asian Journal of Andrology 13 43-52. (doi:10. 1038/aja.2010.76)

Hernandez M, Roca J, Calvete JJ, Sanz L, Muino-Blanco T, CebrianPerez JA, Vazquez JM \& Martinez EA 2007a Cryosurvival and in vitro fertilizing capacity postthaw is improved when boar 
spermatozoa are frozen in the presence of seminal plasma from good freezer boars. Journal of Andrology 28 689-697. (doi:10.2164/jandrol. 107.002725)

Hernandez M, Roca J, Gil MA, Vazquez JM \& Martinez EA 2007b Adjustments on the cryopreservation conditions reduce the incidence of boar ejaculates with poor sperm freezability. Theriogenology 67 1436-1445. (doi:10.1016/j.theriogenology.2007.02.012)

Hollinshead FK, Gillan L, O'Brien JK, Evans G \& Maxwell WMC 2003 In vitro and in vivo assessment of functional capacity of flow cytometrically sorted ram spermatozoa after freezing and thawing. Reproduction, Fertility, and Development 15 351-359. (doi:10.1071/ RD03060)

Holt WV 2000 Fundamental aspects of sperm cryobiology: the importance of species and individual differences. Theriogenology 53 47-58. (doi:10. 1016/S0093-691X(99)00239-3)

Holt WV \& Fazeli A 2010 The oviduct as a complex mediator of mammalian sperm function and selection. Molecular Reproduction and Development 77 934-943. (doi:10.1002/mrd.21234)

Holt WV \& North RD 1984 Partially irreversible cold-induced lipid phase transitions in mammalian sperm plasma membrane domains: freeze fracture study. Journal of Experimental Zoology 230 473-483. (doi:10. 1002/jez.1402300316)

Holt WV \& North RD 1988 The role of membrane active lipids in the protection of ram spermatozoa during cooling and storage. Gamete Research 19 77-89. (doi:10.1002/mrd.1120190108)

Howes EA, Hurst S, Laslop A \& Jones R 1998 Cellular distribution and molecular heterogeneity of MAC393 antigen (clusterin, beta-chain) on the surface membrane of bull spermatozoa. Molecular Human Reproduction 4 673-681. (doi:10.1093/molehr/4.7.673)

Huang S-Y, Pribenszky C, Kuo Y-H, Teng S-H, Chen Y-H, Chung M-T \& Chiu Y-F 2009 Hydrostatic pressure pre-treatment affects the protein profile of boar sperm before and after freezing-thawing. Animal Reproduction Science 112 136-149. (doi:10.1016/j.anireprosci.2008. 04.016)

Hunter RHF 2008 Sperm release from oviduct epithelial binding is controlled hormonally by peri-ovulatory Graafian follicles. Molecular Reproduction and Development 75 167-174. (doi:10.1002/mrd.20776)

Ikawa M, Inoue N, Benham AM \& Okabe M 2010 Fertilization: a sperm's journey to and interaction with the oocyte. Journal of Clinical Investigation 120 984-994. (doi:10.1172/JCl41585)

Inoue N, Ikawa M, Isotani A \& Okabe M 2005 The immunoglobulin superfamily protein Izumo is required for sperm to fuse with eggs. Nature 434 234-238. (doi:10.1038/nature03362)

Jin M, Fujiwara E, Kakiuchi Y, Okabe M, Satouh Y, Baba S, Chiba K \& Hirohashi N 2011 From the cover: most fertilizing mouse spermatozoa begin their acrosome reaction before contact with the zona pellucida during in vitro fertilization. PNAS 108 4892-4896. (doi:10.1073/pnas. 1018202108)

Jobim MIM, Oberst ER, Salbego CG, Souza DO, Wald VB, Tramontina F \& Mattos RC 2004 Two-dimensional polyacrylamide gel electrophoresis of bovine seminal plasma proteins and their relation with semen freezability. Theriogenology 61 255-266. (doi:10.1016/S0093-691X (03)00230-9)

Johnson LA, Flook JP \& Hawk HW 1989 Sex preselection in rabbits: live births from $X$ and $Y$ sperm separated by DNA and cell sorting. Biology of Reproduction 41 199-203. (doi:10.1095/biolreprod41.2.199)

Johnson LA, Weitze KF, Fiser P \& Maxwell WM 2000 Storage of boar semen. Animal Reproduction Science 62 143-172. (doi:10.1016/S0378-4320 (00)00157-3)

Kalthur G, Raj S, Thiyagarajan A, Kumar S, Kumar P \& Adiga SK 2011 Vitamin $\mathbf{E}$ supplementation in semen-freezing medium improves the motility and protects sperm from freeze-thaw-induced DNA damage. Fertility and Sterility 95 1149-1151. (doi:10.1016/j.fertnstert.2010.10. 005)

Katila T \& Kareskoski M 2006 Components of stallion seminal plasma and their influence on spermatozoa. Pferdeheilkunde 22 193-200.

Killian G 2011 Evidence that oviduct secretions influence sperm function: a retrospective view for livestock. Journal of Animal Science 89 1315-1322. (doi:10.2527/jas.2010-3349)

Kirchhoff C, Osterhoff C, Pera I \& Schroter S 1998 Function of human epididymal proteins in sperm maturation. Andrologia 30 225-232. (doi:10.1111/j.1439-0272.1998.tb01164.x)
Kirkwood RN, Vadnais ML \& Abad M 2008 Practical application of seminal plasma. Theriogenology 70 1364-1367. (doi:10.1016/j.theriogenology. 2008.07.018)

Klinc P \& Rath D 2007 Reduction of oxidative stress in bovine spermatozoa during flow cytometric sorting. Reproduction in Domestic Animals 42 63-67. (doi:10.1111/j.1439-0531.2006.00730.x)

Klinc P, Frese D, Osmers H \& Rath D 2007 Insemination with sex sorted fresh bovine spermatozoa processed in the presence of antioxidative substances. Reproduction in Domestic Animals 42 58-62. (doi:10.1111/ j.1439-0531.2006.00729.x)

Koppers AJ, Reddy T \& O'Bryan MK 2011 The role of cysteine-rich secretory proteins in male fertility. Asian Journal of Andrology 13 111-117. (doi:10.1038/aja.2010.77)

de Lamirande E \& Lamothe G 2009 Reactive oxygen-induced reactive oxygen formation during human sperm capacitation. Free Radical Biology \& Medicine 46 502-510. (doi:10.1016/j.freeradbiomed.2008. 11.004)

de Lamirande E \& O'Flaherty C 2008 Sperm activation: role of reactive oxygen species and kinases. Biochimica et Biophysica Acta 1784 106-115. (doi:10.1016/j.bbapap.2007.08.024)

Lane ME, Therien I, Moreau R \& Manjunath P 1999 Heparin and high density lipoprotein mediate bovine sperm capacitation by different mechanisms. Biology of Reproduction 60 169-175. (doi:10.1095/ biolreprod60.1.169)

Leahy T, Marti JI, Evans G \& Maxwell WMC 2009 Seminal plasma proteins protect flow-sorted ram spermatozoa from freeze-thaw damage. Reproduction, Fertility, and Development 21 571-578. (doi:10.1071/ RD08238)

Leahy T, Celi P, Bathgate R, Evans G, Maxwell WMC \& Marti JI 2010a Flow-sorted ram spermatozoa are highly susceptible to hydrogen peroxide damage but are protected by seminal plasma and catalase. Reproduction, Fertility, and Development 22 1131-1140. (doi:10.1071/ RD09286)

Leahy T, Evans G, Maxwell WMC \& Marti JI $2010 b$ Seminal plasma proteins do not consistently improve fertility after cervical insemination of ewes with non-sorted or sex-sorted frozen-thawed ram spermatozoa. Reproduction, Fertility, and Development 22 606-612. (doi:10.1071/ RD09207)

Leahy T, Marti JI, Evans G \& Maxwell WMC 2010c Seasonal variation in the protective effect of seminal plasma on frozen-thawed ram spermatozoa. Animal Reproduction Science 119 147-153. (doi:10.1016/j.anireprosci. 2009.12.010)

Leahy T, Marti J, Crossett B, Evan G \& Maxwell WMC 2011 Two-dimensional polyacrylamide gel electrophoresis of membrane proteins from flow cytometrically sorted ram sperm. Theriogenology $\mathbf{7 5}$ 962-971. (doi:10.1016/j.theriogenology.2010.11.003)

Lee TH, Liu CH, Shih YT, Tsao HM, Huang CC, Chen HH \& Lee MS 2010 Magnetic-activated cell sorting for sperm preparation reduces spermatozoa with apoptotic markers and improves the acrosome reaction in couples with unexplained infertility. Human Reproduction 25 839-846. (doi:10.1093/humrep/deq009)

Lefebvre R \& Suarez SS 1996 Effect of capacitation on bull sperm binding to homologous oviductal epithelium. Biology of Reproduction 54 575-582. (doi:10.1095/biolreprod54.3.575)

Lessard C, Parent S, Leclerc P, Bailey JL \& Sullivan R 2000 Cryopreservation alters the levels of the bull sperm surface protein P25b. Journal of Andrology 21 700-707.

Li JY, Liu FJ, Wang HY, Liu X, Liu JA, Li N, Wan FC, Wang WT, Zhang CL, Jin SH et al. 2010 Systematic mapping and functional analysis of a family of human epididymal secretory sperm-located proteins. Molecular \& Cellular Proteomics 9 2517-2528. (doi:10.1074/mcp.M110.001719)

Li JY, Liu FJ, Liu X, Liu JA, Zhu P, Wan FC, Jin SH, Wang WT, Li N, Liu J et al. 2011 Mapping of the human testicular proteome and its relationship with that of the epididymis and spermatozoa. Molecular \& Cellular Proteomics 10 M110.004630. (doi:10.1074/mcp.M110.004630)

Lin Y \& Kan FWK 1996 Regionalization and redistribution of membrane phospholipids and cholesterol in mouse spermatozoa during in vitro capacitation. Biology of Reproduction 55 1133-1146. (doi:10.1095/ biolreprod55.5.1133)

Lu SH, Yen YK, Ling TY, Cheng KT, Shu JA, Au HK \& Huang YH 2010 Capacitation suppression by mouse seminal vesicle autoantigen involves 
a decrease in plasma membrane $\mathrm{Ca}^{2+}$-ATPase (PMCA)-mediated intracellular calcium. Journal of Cellular Biochemistry 111 1188-1198. (doi:10.1002/jcb.22844)

Lucero HA \& Robbins PW 2004 Lipid rafts-protein association and the regulation of protein activity. Archives of Biochemistry and Biophysics 426 208-224. (doi:10.1016/j.abb.2004.03.020)

Lusignan MF, Bergeron A, Crete MH, Lazure C \& Manjunath P 2007 Induction of epididymal boar sperm capacitation by pB1 and BSP-A1/A2 proteins, members of the BSP protein family. Biology of Reproduction 76 424-432. (doi:10.1095/biolreprod.106.055624)

Maldjian A, Pizzi F, Gliozzi T, Cerolini S, Penny P \& Noble R 2005 Changes in sperm quality and lipid composition during cryopreservation of boar semen. Theriogenology 63 411-421. (doi:10.1016/j.theriogenology. 2004.09.021)

Malo C, Gil L, Gonzalez N, Martinez F, Cano R, de Blas I \& Espinosa E 2010 Anti-oxidant supplementation improves boar sperm characteristics and fertility after cryopreservation: comparison between cysteine and rosemary (Rosmarinus officinalis). Cryobiology 61 142-147. (doi:10. 1016/j.cryobiol.2010.06.009)

Manjunath P, Nauc V, Bergeron A \& Menard M 2002 Major proteins of bovine seminal plasma bind to the low-density lipoprotein fraction of hen's egg yolk. Biology of Reproduction 67 1250-1258. (doi:10.1095/ biolreprod67.4.1250)

Manjunath P, Bergeron A, Lefebvre J \& Fan J 2007 Seminal plasma proteins: functions and interaction with protective agents during semen preservation. Society of Reproduction and Fertility Supplement 65 217-228.

Manjunath P, Lefebvre J, Jois PS, Fan JJ \& Wright MW 2009 New nomenclature for mammalian BSP genes. Biology of Reproduction $\mathbf{8 0}$ 394-397. (doi:10.1095/biolreprod.108.074088)

Marti E, Marti JI, Muino-Blanco T \& Cebrian-Perez JA 2008 Effect of the cryopreservation process on the activity and immunolocalization of antioxidant enzymes in ram spermatozoa. Journal of Andrology 29 459-467. (doi:10.2164/jandrol.107.003459)

Martins SG, Miranda PV \& Brandelli A 2003 Acrosome reaction inhibitor released during in vitro sperm capacitation. International Journal of Andrology 26 296-304. (doi:10.1046/j.1365-2605.2003.00429.x)

Maxwell WMC \& Johnson LA 1997 Chlortetracycline analysis of boar spermatozoa after incubation, flow cytometric sorting, cooling, or cryopreservation. Molecular Reproduction and Development 46 408-418. (doi:10.1002/(SICl)1098-2795(199703)46:3<408::AIDMRD21 > 3.0.CO;2-T)

Maxwell WMC \& Stojanov T 1996 Liquid storage of ram semen in the absence or presence of some antioxidants. Reproduction, Fertility, and Development 8 1013-1020. (doi:10.1071/RD9961013)

Maxwell WMC \& Watson PF 1996 Recent progress in the preservation of ram semen. Animal Reproduction Science 42 55-65. (doi:10.1016/ 0378-4320(96)01544-8)

Maxwell WMC, Welch GR \& Johnson LA 1996 Viability and membrane integrity of spermatozoa after dilution and flow cytometric sorting in the presence or absence of seminal plasma. Reproduction, Fertility, and Development 8 1165-1178. (doi:10.1071/RD9961165)

Maxwell WMC, Long CR, Johnson LA, Dobrinsky JR \& Welch GR 1998 The relationship between membrane status and fertility of boar spermatozoa after flow cytometric sorting in the presence or absence of seminal plasma. Reproduction, Fertility, and Development 10 433-440. (doi:10.1071/RD98102)

Maxwell WMC, Evans G, Mortimer ST, Gillan L, Gellatly ES \& McPhie CA 1999 Normal fertility in ewes after cervical insemination with frozenthawed spermatozoa supplemented with seminal plasma. Reproduction, Fertility, and Development 11 123-126. (doi:10.1071/RD99046)

Maxwell WMC, Evans G, Hollinshead FK, Bathgate R, de Graaf SP, Eriksson BM, Gillan L, Morton KM \& O'Brien JK 2004 Integration of sperm sexing technology into the ART toolbox. Animal Reproduction Science 82-83 79-95. (doi:10.1016/j.anireprosci.2004.04.013)

Maxwell WMC, de Graaf SP, El-Hajj Ghaoui R \& Evans G 2007 Seminal plasma effects on sperm handling and female fertility. Reproduction in Domestic Ruminants 64 13-37. (doi:10.5661/RDR-VI-13)

Mayorga LS, Tomes CN \& Belmonte SA 2007 Acrosomal exocytosis, a special type of regulated secretion. IUBMB Life $\mathbf{5 9}$ 286-292. (doi:10. 1080/15216540701222872)
McCarthy AN \& Grigera JR 2006 Effect of pressure on the conformation of proteins. A molecular dynamics simulation of lysozyme. Journal of Molecular Graphics \& Modelling 24 254-261. (doi:10.1016/j.jmgm. 2005.09.007)

McNutt TL \& Johnson LA 1996 Electrophoretic gel analysis of Hoechst 33342 stained and flow cytometrically sorted bovine sperm membrane proteins. Reproduction in Domestic Animals 31 703-709. (doi:10.1111/ j.1439-0531.1996.tb01442.x)

Metayer S, Dacheux F, Guerin Y, Dacheux JL \& Gatti JL 2001 Physiological and enzymatic properties of the ram epididymal soluble form of germinal angiotensin I-converting enzyme. Biology of Reproduction $\mathbf{6 5}$ 1332-1339. (doi:10.1095/biolreprod65.5.1332)

Moce E \& Graham JK 2006 Cholesterol-loaded cyclodextrins added to fresh bull ejaculates improve sperm cryosurvival. Journal of Animal Science 84 826-833.

Moce E, Graham JK \& Schenk JL 2006 Effect of sex-sorting on the ability of fresh and cryopreserved bull sperm to undergo an acrosome reaction. Theriogenology 66 929-936. (doi:10.1016/j.theriogenology. 2006.01.063)

Moce E, Purdy PH \& Graham JK 2010 Treating ram sperm with cholesterolloaded cyclodextrins improves cryosurvival. Animal Reproduction Science 118 236-247. (doi:10.1016/j.anireprosci.2009.06.013)

Montfort L, Frenette G \& Sullivan R 2002 Sperm-zona pellucida interaction involves a carbonyl reductase activity in the hamster. Molecular Reproduction and Development 61 113-119. (doi:10.1002/mrd.1137)

Moore AI, Squires EL \& Graham JK 2005 Adding cholesterol to the stallion sperm plasma membrane improves cryosurvival. Cryobiology $\mathbf{5 1}$ 241-249. (doi:10.1016/j.cryobiol.2005.07.004)

Moraes EA, Graham JK, Torres CAA, Meyers M \& Spizziri B 2010 Delivering cholesterol or cholestanol to bull sperm membranes improves cryosurvival. Animal Reproduction Science 118 148-154. (doi:10.1016/ j.anireprosci.2009.08.002)

Morin G, Sullivan R, Laflamme I, Robert C \& Leclerc P 2010 SPAM1 isoforms from two tissue origins are differentially localized within ejaculated bull sperm membranes and have different roles during fertilization. Biology of Reproduction 82 271-281. (doi:10.1095/biolreprod.109.079582)

Mortimer D 2000 Sperm preparation methods. Journal of Andrology 21 357-366.

Muino-Blanco T, Perez-Pe R \& Cebrian-Perez JA 2008 Seminal plasma proteins and sperm resistance to stress. Reproduction in Domestic Animals 43 18-31. (doi:10.1111/j.1439-0531.2008.01228.x)

Nakagata N 2000 Cryopreservation of mouse spermatozoa. Mammalian Genome 11 572-576. (doi:10.1007/s003350010109)

Neild DM, Brouwers J, Colenbrander B, Aguero A \& Gadella BM 2005 Lipid peroxide formation in relation to membrane stability of fresh and frozen thawed stallion spermatozoa. Molecular Reproduction and Development 72 230-238. (doi:10.1002/mrd.20322)

Nixon B, MacIntyre DA, Mitchell LA, Gibbs GM, O'Bryan M \& Aitken RJ 2006 The identification of mouse sperm-surface-associated proteins and characterization of their ability to act as decapacitation factors. Biology of Reproduction 74 275-287. (doi:10.1095/biolreprod.105. 044644)

Nixon B, Bielanowicz A, McLaughlin EA, Tanphaichitr N, Ensslin MA \& Aitken RJ 2009 Composition and significance of detergent resistant membranes in mouse spermatozoa. Journal of Cellular Physiology 218 122-134. (doi:10.1002/jcp.21575)

Nixon B, Mitchell LA, Anderson A, McLaughlin EA, O'Bryan MK \& Aitken RJ 2011 Proteomic and functional analysis of human sperm detergent resistant membranes. Journal of Cellular Physiology 226 2651-2665. (doi:10.1002/jcp.22615)

O'Flaherty C, de Lamirande E \& Gagnon C 2006 Positive role of reactive oxygen species in mammalian sperm capacitation: triggering and modulation of phosphorylation events. Free Radical Biology \& Medicine 41 528-540. (doi:10.1016/j.freeradbiomed.2006.04.027)

Okamura N, Kiuchi S, Tamba M, Kashima T, Hiramoto S, Baba T, Dacheux F, Dacheux JL, Sugita Y \& Jin YZ 1999 A porcine homolog of the major secretory protein of human epididymis, HE1, specifically binds cholesterol. Biochimica et Biophysica Acta 1438 377-387. (doi:10. 1016/S1388-1981(99)00070-0)

Okazaki T, Abe S, Yoshida S \& Shimada M 2009 Seminal plasma damages sperm during cryopreservation, but its presence during thawing improves 
semen quality and conception rates in boars with poor post-thaw semen quality. Theriogenology 71 491-498. (doi:10.1016/j.theriogenology. 2008.08.014)

Oldenhof H, Friedel K, Sieme H, Glasmacher B \& Wolkers WF 2010 Membrane permeability parameters for freezing of stallion sperm as determined by Fourier transform infrared spectroscopy. Cryobiology $\mathbf{6 1}$ 115-122. (doi:10.1016/j.cryobiol.2010.06.002)

Oliveira CH, Vasconcelos AB, Souza FA, Martins OA, Silva MX, Varago FC \& Lagares MA 2010 Cholesterol addition protects membrane intactness during cryopreservation of stallion sperm. Animal Reproduction Science 118 194-200. (doi:10.1016/j.anireprosci.2009.08.011)

Ollero M, Cebrian-Perez JA \& Muino-Blanco T 1997 Improvement of cryopreserved ram sperm heterogeneity and viability by addition of seminal plasma. Journal of Andrology 18 732-739.

Ollero M, Bescos O, Cebrian-Perez JA \& Muino-Blanco T 1998 Loss of plasma membrane proteins of bull spermatozoa through the freezingthawing process. Theriogenology 49 547-555. (doi:10.1016/S0093691X(98)00006-5)

O'Meara CM, Donovan A, Hanrahan JP, Duffy P, Fair S, Evans ACO \& Lonergan P 2007 Resuspending ram spermatozoa in seminal plasma after cryopreservation does not improve pregnancy rate in cervically inseminated ewes. Theriogenology 67 1262-1268. (doi:10.1016/j. theriogenology.2007.01.012)

Overstreet JW, Cooper GW \& Katz DF 1978 Sperm transport in the reproductive tract of the female rabbit: II Sustained phase of transport. Biology of Reproduction 19 115-132. (doi:10.1095/biolreprod19.1.115)

Paasch U, Grunewald S \& Glander H-J 2007 Sperm selection in assisted reproductive techniques. Society of Reproduction and Fertility Supplement 65 515-525.

Pace MM \& Graham EF 1974 Components in egg yolk which protect bovine spermatozoa during freezing. Journal of Animal Science 39 1144-1149.

Parent S, Lefievre L, Brindle Y \& Sullivan R 1999 Bull subfertility is associated with low levels of a sperm membrane antigen. Molecular Reproduction and Development 52 57-65. (doi:10.1002/(SICI)10982795(199901)52:1 < 57::AID-MRD8 > 3.0.CO;2-U)

Parinaud J, Vieitez G, Vieu C, Collet X \& Perret B 2000 Enhancement of zona binding using 2-hydroxypropyl-beta-cyclodextrin. Human Reproduction 15 1117-1120. (doi:10.1093/humrep/15.5.1117)

Parks JE \& Graham JK 1992 Effects of cryopreservation procedures on sperm membranes. Theriogenology 38 209-222. (doi:10.1016/0093691X(92)90231-F)

Parrilla I, Vazquez JM, Caballero M, Alminana C, Roca J \& Martinez EA 2005 Influence of storage time on functional capacity of flow cytometrically sex-sorted boar spermatozoa. Theriogenology 64 86-98. (doi:10.1016/j.theriogenology.2004.11.004)

Parrish JJ, Suskoparrish J, Winer MA \& First NL 1988 Capacitation of bovine spermatozoa by heparin. Biology of Reproduction $\mathbf{3 8}$ 1171-1180. (doi:10.1095/biolreprod38.5.1171)

Parrish JJ, Suskoparrish JL, Handrow RR, Sims MM \& First NL 1989 Capacitation of bovine spermatozoa by oviduct fluid. Biology of Reproduction 40 1020-1025. (doi:10.1095/biolreprod40.5.1020)

Perez-Pe R, Muino-Blanco T \& Cebrian-Perez JA 2001 Sperm washing method alters the ability of seminal plasma proteins to revert the coldshock damage on ram sperm membrane. International Journal of Andrology 24 352-359. (doi:10.1046/j.1365-2605.2001.00315.x)

Petrunkina AM \& Töpfer-Petersen E 2000 Heterogeneous osmotic behaviour in boar sperm populations and its relevance for detection of changes in plasma membrane. Reproduction, Fertility, and Development 12 297-305. (doi:10.1071/RD00087)

Pettitt MJ \& Buhr MM 1998 Extender components and surfactants affect boar sperm function and membrane behavior during cryopreservation. Journal of Andrology 19 736-746.

Polge C, Smith AU \& Parkes AS 1949 Revival of spermatozoa after vitrification and dehydration at low temperatures. Nature 164666. (doi:10.1038/164666a0)

Pribenszky C \& Vajta G 2011 Cells under pressure: how sublethal hydrostatic pressure stress treatment increases gametes' and embryos' performance? Reproduction, Fertility, and Development 23 48-55. (doi:10.1071/RD10231)
Pribenszky C, Vajta G, Molnar M, Du YT, Lin L, Bolund L \& Yovich J 2010 Stress for stress tolerance? A fundamentally new approach in mammalian embryology Biology of Reproduction 83 690-697. (doi:10.1095/ biolreprod.110.083386)

Purdy PH \& Graham JK 2004 Effect of adding cholesterol to bull sperm membranes on sperm capacitation, the acrosome reaction, and fertility. Biology of Reproduction 71 522-527. (doi:10.1095/biolreprod.103. 025577)

Rath D, Bathgate R, Rodriguez-Martinez H, Roca J, Strzezek J \& Waberski D 2009a Recent advances in boar semen cryopreservation. Society of Reproduction and Fertility Supplement 66 51-66.

Rath D, Moench-Tegeder G, Taylor U \& Johnson LA $2009 \mathrm{~b}$ Improved quality of sex-sorted sperm: a prerequisite for wider commercial application. Theriogenology 71 22-29. (doi:10.1016/j.theriogenology. 2008.09.027)

Reid AT, Redgrove K, Aitken RJ \& Nixon B 2011 Cellular mechanisms regulating sperm-zona pellucida interaction. Asian Journal of Andrology 13 88-96. (doi:10.1038/aja.2010.74)

Ricker JV, Linfor JJ, Delfino WJ, Kysar P, Scholtz EL, Tablin F, Crowe JH, Ball BA \& Meyers SA 2006 Equine sperm membrane phase behavior: the effects of lipid-based cryoprotectants. Biology of Reproduction $\mathbf{7 4}$ 359-365. (doi:10.1095/biolreprod.105.046185)

Roberts KP, Ensrud KM, Wooters JL, Nolan MA, Johnston DS \& Hamilton DW 2006 Epididymal secreted protein Crisp-1 and sperm function. Molecular and Cellular Endocrinology 250 122-127. (doi:10. 1016/j.mce.2005.12.034)

Roca J, Hernandez M, Carvajal G, Vazquez JM \& Martinez EA 2006 Factors influencing boar sperm cryosurvival. Journal of Animal Science 84 2692-2699. (doi:10.2527/jas.2006-094)

Rodriguez PC \& Beconi MT 2009 Peroxynitrite participates in mechanisms involved in capacitation of cryopreserved cattle. Animal Reproduction Science 110 96-107. (doi:10.1016/j.anireprosci.2007.12.017)

Rodriguez PC, Valdez LB, Zaobornyj T, Boveris A \& Beconi MT 2011 Nitric oxide and superoxide anion production during heparin-induced capacitation in cryopreserved bovine spermatozoa. Reproduction in Domestic Animals 46 74-81. (doi:10.1111/j.1439-0531.2010.01583.x)

Rodriguez-Martinez H 2007 Role of the oviduct in sperm capacitation. Theriogenology 68 S138-S146. (doi:10.1016/j.theriogenology.2007. 03.018)

Saez F, Ouvrier A \& Drevet JR 2011 Epididymis cholesterol homeostasis and sperm fertilizing ability. Asian Journal of Andrology 13 11-17. (doi:10.1038/aja.2010.64)

Said TM, Agarwal A, Zborowski M, Grunewald S, Glander HJ \& Paasch U 2008 Utility of magnetic cell separation as a molecular sperm preparation technique. Journal of Andrology 29 134-142. (doi:10. 2164/jandrol.107.003632)

Sakkas D, Manicardi GC, Tomlinson M, Mandrioli M, Bizzaro D, Bianchi PG \& Bianchi U 2000 The use of two density gradient centrifugation techniques and the swim-up method to separate spermatozoa with chromatin and nuclear DNA anomalies. Human Reproduction 15 1112-1116. (doi:10. 1093/humrep/15.5.1112)

Salamon S \& Maxwell WMC 1995a Frozen storage of ram semen I. Processing, freezing, thawing and fertility after cervical insemination. Animal Reproduction Science 37 185-249. (doi:10.1016/0378-4320 (94)01327-I)

Salamon S \& Maxwell WMC 1995b Frozen storage of ram semen II. Causes of low fertility after cervical insemination and methods of improvement. Animal Reproduction Science 38 1-36. (doi:10.1016/03784320(94)01328-J)

Salamon S \& Maxwell WMC 2000 Storage of ram semen. Animal Reproduction Science 62 77-111. (doi:10.1016/S0378-4320(00) 00155-X)

Sanz L, Calvete JJ, Mann K, Gabius HJ \& Topferpetersen E 1993 Isolation and biochemical-characterization of heparin-binding proteins from boar seminal plasma - a dual role for spermadhesins in fertilization. Molecular Reproduction and Development 35 37-43. (doi:10.1002/ mrd.1080350107)

Saravia F, Wallgren M, Johannisson A, Calvete JJ, Sanz L, Pena FJ, Roca J \& Rodriguez-Martinez H 2009 Exposure to the seminal plasma of different portions of the boar ejaculate modulates the survival of spermatozoa cryopreserved in MiniFlatPacks. Theriogenology 71 662-675. (doi:10. 1016/j.theriogenology.2008.09.037) 
Seaton GJ, Hall L \& Jones R 2000 Rat sperm 2B1 glycoprotein (PH20) contains a C-terminal sequence motif for attachment of a glycosyl phosphatidylinositol anchor. Effects of endoproteolytic cleavage on hyaluronidase activity. Biology of Reproduction 62 1667-1676. (doi:10. 1095/biolreprod62.6.1667)

Seidel GE Jr \& Garner DL 2002 Current status of sexing mammalian spermatozoa. Reproduction 124 733-743. (doi:10.1530/rep.0.1240733)

Seita Y, Sugio S, Ito J \& Kashiwazaki N 2009 Generation of live rats produced by in vitro fertilization using cryopreserved spermatozoa. Biology of Reproduction 80 503-510. (doi:10.1095/biolreprod.108. 072918)

Selvaraj V, Asano A, Buttke DE, Sengupta P, Weiss RS \& Travis AJ 2009 Mechanisms underlying the micron-scale segregation of sterols and G(M1) in live mammalian sperm. Journal of Cellular Physiology 218 522-536. (doi:10.1002/jcp.21624)

Serin I, Aksoy M \& Ceylan A 2011 Cholesterol-loaded cyclodextrin inhibits premature acrosomal reactions in liquid-stored rabbit spermatozoa. Animal Reproduction Science 123 106-111. (doi:10.1016/j.anireprosci. 2010.10.014)

Shadan S, James P, Howes E \& Jones R 2004 Cholesterol efflux alters lipid raft stability and distribution during capacitation of boar spermatozoa. Biology of Reproduction 71 253-265. (doi:10.1095/biolreprod.103. 026435)

Shekarriz M, Dewire DM, Thomas AJ \& Agarwal A 1995 A method of human semen centrifugation to minimize the iatrogenic sperm injuries caused by reactive oxygen species. European Urology 28 31-35.

Shur BD, Rodeheffer C, Ensslin MA, Lyng R \& Raymond A 2006 Identification of novel gamete receptors that mediate sperm adhesion to the egg coat. Molecular and Cellular Endocrinology 250 137-148. (doi:10.1016/j.mce.2005.12.037)

Songsasen N \& Leibo SP 1997 Cryopreservation of mouse spermatozoa. 2. Relationship between survival after cryopreservation and osmotic tolerance of spermatozoa from three strains of mice. Cryobiology 35 255-269. (doi:10.1006/cryo.1997.2047)

Sostaric E, Dieleman SJ, Van De Lest CHA, Colenbrander B, Vos P, GarciaGil N \& Gadella BM 2008 Sperm binding properties and secretory activity of the bovine oviduct immediately before and after ovulation. Molecular Reproduction and Development 75 60-74. (doi:10.1002/mrd. 20766)

Spinaci M, Volpe S, Bernardint C, De Ambrogi M, Tamanini C, Seren E \& Galeati G 2006 Sperm sorting procedure induces a redistribution of Hsp70 but not Hsp60 and Hsp90 in boar spermatozoa. Journal of Andrology 27 899-907. (doi:10.2164/jandrol.106.001008)

Spizziri BE, Fox MH, Bruemmer JE, Squires EL \& Graham JK 2010 Cholesterol-loaded-cyclodextrins and fertility potential of stallions spermatozoa. Animal Reproduction Science 118 255-264. (doi:10. 1016/j.anireprosci.2009.08.001)

Storey BT 2008 Mammalian sperm metabolism: oxygen and sugar, friend and foe. International Journal of Developmental Biology 52 427-437. (doi:10.1387/ijdb.072522bs)

Suarez SS 2008 Regulation of sperm storage and movement in the mammalian oviduct. International Journal of Developmental Biology 52 455-462. (doi:10.1387/ijdb.072527ss)

Suryawanshi AR, Khan SA, Gajbhiye RK, Gurav MY \& Khole VV 2011 Differential proteomics leads to identification of domain-specific epididymal sperm proteins. Journal of Andrology 32 240-259. (doi:10. 2164/jandrol.110.010967)

Suzuki K, Asano A, Eriksson B, Niwa K, Nagai T \& Rodriguez-Martinez H 2002 Capacitation status and in vitro fertility of boar spermatozoa: effects of seminal plasma, cumulus-oocyte complexes conditioned medium and hyaluronan. International Journal of Andrology 25 84-93. (doi:10. 1046/j.1365-2605.2002.00330.x)

Syntin P, Dacheux F, Druart X, Gatti JL, Okamura N \& Dacheux JL 1996 Characterization and identification of proteins secreted in the various regions of the adult boar epididymis. Biology of Reproduction $\mathbf{5 5}$ 956-974. (doi:10.1095/biolreprod55.5.956)

Takeo T, Hoshii T, Kondo Y, Toyodome H, Arima H, Yamamura KI, Irie T \& Nakagata N 2008 Methyl-beta-cyclodextrin improves fertilizing ability of $\mathrm{C} 57 \mathrm{BL} / 6$ mouse sperm after freezing and thawing by facilitating cholesterol efflux from the cells. Biology of Reproduction 78 546-551. (doi:10.1095/biolreprod.107.065359)
Thaler CD \& Cardullo RA 1995 Biochemical characterization of a glycosylphosphatidylinositol linked hyaluronidase on mouse sperm. Biochemistry 34 7788-7795. (doi:10.1021/bi00024a002)

Therien I, Moreau R \& Manjunath P 1998 Major proteins of bovine seminal plasma and high-density lipoprotein induce cholesterol efflux from epididymal sperm. Biology of Reproduction 59 768-776. (doi:10.1095/ biolreprod59.4.768)

Therien I, Moreau R \& Manjunath P 1999 Bovine seminal plasma phospholipid-binding proteins stimulate phospholipid efflux from epididymal sperm. Biology of Reproduction 61 590-598. (doi:10.1095/ biolreprod61.3.590)

Thomas AD, Meyers SA \& Ball BA 2006 Capacitation-like changes in equine spermatozoa following cryopreservation. Theriogenology $\mathbf{6 5}$ 1531-1550. (doi:10.1016/j.theriogenology.2005.08.022)

Thurston LM, Siggins K, Mileham AJ, Watson PF \& Holt WV 2002 Identification of amplified restriction fragment length polymorphism markers linked to genes controlling boar sperm viability following cryopreservation. Biology of Reproduction 66 545-554. (doi:10.1095/biolreprod66.3.545)

Tomes CN 2007 Molecular mechanisms of membrane fusion during acrosomal exocytosis. Society of Reproduction and Fertility Supplement $65275-291$.

Topfer-Petersen E, Waberski D, Hess O, Bellair S, Schambony A, EkhlasiHundrieser M, Gentzel M \& Reineke A 1998 The role of seminal plasma in fertilisation. Tierarztliche Umschau 53 447-454.

Travis AJ \& Kopf GS 2002 The role of cholesterol efflux in regulating the fertilization potential of mammalian spermatozoa. Journal of Clinical Investigation 110 731-736. (doi:10.1172/JCI16392)

Tsai PS \& Gadella BM 2009 Molecular kinetics of proteins at the surface of porcine sperm before and during fertilization. Society of Reproduction and Fertility Supplement 66 23-36.

Tsai PS, De Vries KJ, De Boer-Brouwer M, Garcia-Gil N, Van Gestel RA, Colenbrander B, Gadella BM \& Van Haeften T 2007 Syntaxin and VAMP association with lipid rafts depends on cholesterol depletion in capacitating sperm cells. Molecular Membrane Biology 24 313-324. (doi:10.1080/09687860701228692)

Tsai P-S, Garcia-Gil N, van Haeften T \& Gadella BM 2010 How pig sperm prepares to fertilize: stable acrosome docking to the plasma membrane. PLOS ONE 5 e11204. (doi:10.1371/journal.pone.0011204)

Twigg J, Irvine SD, Houston P, Fulton N, Michael L \& Aitken RJ 1998 Latrogenic DNA damage induced in human spermatozoa during sperm preparation: protective significance of seminal plasma. Molecular Human Reproduction 4 439-445. (doi:10.1093/molehr/4.5.439)

Underwood SL, Bathgate R, Ebsworth M, Maxwell WMC \& Evans G 2009a Pregnancy loss in heifers after artificial insemination with frozen-thawed, sex-sorted, re-frozen-thawed dairy bull sperm. Animal Reproduction Science 118 7-12. (doi:10.1016/j.anireprosci.2009.06.004)

Underwood SL, Bathgate R, Maxwell WMC \& Evans G 2009b Birth of offspring after artificial insemination of heifers with frozen-thawed, sex-sorted, re-frozen-thawed bull sperm. Animal Reproduction Science 118 171-175. (doi:10.1016/j.anireprosci.2009.08.007)

Underwood SL, Bathgate R, Maxwell WMC \& Evans G 2009c In vitro characteristics of frozen-thawed, sex-sorted bull sperm after refreezing or incubation at 15 or $37^{\circ} \mathrm{C}$. Theriogenology 72 1001-1008. (doi:10. 1016/j.theriogenology.2009.06.023)

Urrego R, Rios A, Angel MO \& Camargo O 2008 Effect of centrifugation on plasma membrane and DNA of bovine spermatozoa. Revista Colombiana De Ciencias Pecuarias 21 19-26.

Vadnais ML \& Roberts KP 2007 Effects of seminal plasma on coolinginduced capacitative changes in boar sperm. Journal of Andrology $\mathbf{2 8}$ 416-422. (doi:10.2164/jandrol.106.001826)

Vadnais ML \& Roberts KP 2010 Seminal plasma proteins inhibit in vitroand cooling-induced capacitation in boar spermatozoa. Reproduction, Fertility, and Development 22 893-900. (doi:10.1071/RD09274)

Vazquez JM, Parrilla I, Roca J, Gil MA, Cuello C, Vazquez JL \& Martínez EA 2009 Sex-sorting sperm by flow cytometry in pigs: issues and perspectives. Theriogenology 71 80-88. (doi:10.1016/j.theriogenology. 2008.09.044)

Visconti PE, Moore GD, Bailey JL, Leclerc P, Connors SA, Pan DY, Oldsclarke P \& Kopf GS 1995 Capacitation of mouse spermatozoa. 2. Protein-tyrosine phosphorylation and capacitation are regulated by a Camp-dependent pathway. Development 121 1139-1150. 
Visconti PE, Ning XP, Fornes MW, Alvarez JG, Stein P, Connors SA \& Kopf GS 1999 Cholesterol efflux-mediated signal transduction in mammalian sperm: cholesterol release signals an increase in protein tyrosine phosphorylation during mouse sperm capacitation. Developmental Biology 214 429-443. (doi:10.1006/dbio.1999.9428)

Vishwanath R 2003 Artificial insemination: the state of the art. Theriogenology 59 571-584. (doi:10.1016/S0093-691X(02)01241-4)

Vishwanath R \& Shannon P 2000 Storage of bovine semen in liquid and frozen state. Animal Reproduction Science 62 23-53. (doi:10.1016/ S0378-4320(00)00153-6)

Vreeburg JTM, Holland MK \& Orgebincrist MC 1992 Binding of epididymal proteins to rat spermatozoa in vivo. Biology of Reproduction 47 588-597. (doi:10.1095/biolreprod47.4.588)

de Vries KJ, Wiedmer T, Sims PJ \& Gadella BM 2003 Caspase-independent exposure of aminophospholipids and tyrosine phosphorylation in bicarbonate responsive human sperm cells. Biology of Reproduction 68 2122-2134. (doi:10.1095/biolreprod.102.012500)

Watson PF 1981 The roles of lipid and protein in the protection of ram spermatozoa at 5 degrees $\mathrm{C}$ by egg-yolk lipoprotein. Journal of Reproduction and Fertility 62 483-492. (doi:10.1530/jrf.0.0620483)

Watson PF 1995 Recent developments and concepts in the cyropreservation of spermatozoa and the assessment of their post-thawing function. Reproduction, Fertility, and Development 7 871-891. (doi:10.1071/ RD9950871)

Watson PF 2000 The causes of reduced fertility with cryopreserved semen. Animal Reproduction Science 60-61 481-492. (doi:10.1016/S03784320(00)00099-3)

Witte TS \& Schafer-Somi S 2007 Involvement of cholesterol, calcium and progesterone in the induction of capacitation and acrosome reaction of mammalian spermatozoa. Animal Reproduction Science 102 181-193. (doi:10.1016/j.anireprosci.2007.07.007)
Wu JM, Chung YK, Belford KJ, Smith GD, Takayama S \& Lahann J 2006 A surface-modified sperm sorting device with long-term stability. Biomedical Microdevices 8 99-107. (doi:10.1007/s10544006-7705-7)

Yamaguchi R, Muro Y, Isotani A, Tokuhiro K, Takumi K, Adham I, Ikawa M \& Okabe $\mathbf{M} 2009$ Disruption of ADAM3 impairs the migration of sperm into oviduct in mouse. Biology of Reproduction 81 142-146. (doi:10. 1095/biolreprod.108.074021)

Yanagimachi R 1994 Mammalian fertilization. In The Physiology of Reproduction, 2nd edn, pp 189-317. Eds E Knobil \& JD Neill. New York: Raven Press.

Yanagimachi R 2011 Mammalian sperm acrosome reaction: where does it begin before fertilization? Biology of Reproduction 85 4-5. (doi:10.1095/ biolreprod.111.092601)

Yu I, Songsasen N, Godke RA \& Leibo SP 2002 Differences among dogs in response of their spermatozoa to cryopreservation using various cooling and warming rates. Cryobiology 44 62-78. (doi:10.1016/S00112240(02)00005-6)

Zee YP, Holt WV, Gosalvez J, Allen CD, Nicolson V, Pyne M, Burridge M, Carrick FN \& Johnston SD 2008 Dimethylacetamide can be used as an alternative to glycerol for the successful cryopreservation of koala (Phascolarctos cinereus) spermatozoa. Reproduction, Fertility, and Development 20 724-733. (doi:10.1071/RD08036)

Zhao L, Burkin HR, Shi X, Li L, Reim K \& Miller DJ 2007 Complexin I is required for mammalian sperm acrosomal exocytosis. Developmental Biology 309 236-244. (doi:10.1016/j.ydbio.2007.07.009)

Received 22 August 2011

First decision 27 September 2011

Accepted 27 September 2011 